Research Report No. 18/2008

\title{
Public Justice, Private Dispute Resolution and Democracy
}

Trevor C. W. Farrow

Osgoode Hall Law School of York University, tfarrow@osgoode.yorku.ca

Follow this and additional works at: http://digitalcommons.osgoode.yorku.ca/clpe

Part of the Dispute Resolution and Arbitration Commons

\section{Recommended Citation}

Farrow, Trevor C. W., "Public Justice, Private Dispute Resolution and Democracy" (2008). Comparative Research in Law \& Political Economy. Research Paper No. 18/2008.

http://digitalcommons.osgoode.yorku.ca/clpe/192 


\section{Comparative Research in Law \& Political Economy}

Trevor Farrow

Public J ustice, Private Dispute Resolution and Democracy

Forthcoming in Canadian Institute for the Administration of J ustice (2008)

EDITORS: Peer Zumbansen (Osgoode Hall Law School, Toronto, Director, Comparative Research in Law and Political Economy, York University), J ohn W. Cioffi (University of California at Riverside), Lindsay Krauss (Osgoode Hall Law School, Toronto, Production Editor) 

CLPE Research Paper 18/2008

Vol. 04 No. 04 (2008)

\title{
Trevor Farrow
}

\section{Public Justice, Private Dispute Resolution and DEMOCRACY}

\begin{abstract}
This paper is about the widespread and systematic privatization of the public civil justice system. In particular, it: (1) documents the move to privatize civil disputes across all aspects of the justice system (including courts, administrative tribunals and state-sanctioned arbitration regimes); (2) looks at some of the benefits and drawbacks of privatization, specifically including negative impacts on systems of democratic governance; and (3) identifies justice - rather than efficiency - as the primary benchmark by which civil justice reform initiatives should be judged.
\end{abstract}

Keywords: privatization, civil justice, administrative law, alternative dispute resolution, arbitration, democracy, efficiency, reform

JEL classification: K23, K41

\author{
Author Contact: \\ Trevor Farrow \\ Osgoode Hall Law School, York University \\ 4700 Keele St. Toronto ON M3J 1P3 \\ Email: tfarrow@osgoode.yorku.ca
}




\title{
Public Justice, Private Dispute Resolution And DEMOCRACY
}

\author{
Trevor Farrow ${ }^{*}$
}

\section{INTRODUCTION}

\section{A. HEADING 2}

This article is about the privatization of the civil dispute resolution system, and in particular, the resulting ramifications for democracy. Privatization is occurring at all levels of the public justice system. First, in the civil justice system, there is an increasingly overwhelming tendency to resolve disputes through mechanisms other than the traditional public court process. For example, mandatory court-based mediation rules, judicial dispute resolution initiatives, case management regimes, pre-trial conferences, and cost-based settlement incentives have all become central pillars of modern civil justice system tools and reforms that - either directly or indirectly - encourage the resolution of disputes through methods that are outside of the formal, public trial process.

Second, alongside civil court initiatives, privatization is occurring in the administrative system as well. Tribunals and other administrative processes are increasingly experimenting with formal and informal alternatives to their traditional hearing-based processes. Third, nonadministrative legislative regimes - typically including arbitration statutes - also continue to sanction (and encourage) the resolution of civil disputes outside the formal court system. Fourth, privatization is also occurring in

\footnotetext{
* Osgoode Hall Law School, York University. I am very grateful to the Canadian Institute for the Administration of Justice (CIAJ) for awarding me the 2007 Charles D. Gonthier Research Fellowship, which made the research for this article possible. I am also grateful to the CIAJ for providing me with the opportunity to present this article as the closing paper at the 2007 CIAJ annual meeting in Halifax, Nova Scotia on 12 October 2007. Patricia Hania, Ada Ho and Alan Melamud provided excellent research assistance for various aspects of this article, for which I am also extremely grateful.
} 
parts of the criminal justice system. Although the state is essentially always part of the criminal process, plea-bargaining, community-based diversion programs and restorative justice initiatives have been - and are increasingly becoming - significant alternatives (or complements) to the more formal, public trial-based criminal dispute resolution system. Finally, all of these state-based privatized (or privatizing) systems - civil, administrative, legislative and criminal - are in addition to the already robust, millennia-old tradition of resolving most disputes through mechanisms entirely separate from formal state processes (private negotiations, religious and community-based dispute resolution tools, etc.).

There are many sound and well-documented reasons for these privatizing trends, including reduced costs, increased speed and efficiency, privacy, enhanced autonomy through increased party choice within and control over dispute resolution processes, etc. However, there are also a number of costs to these trends relating to, or involving negative impacts on the development of the common law, potential procedural unfairness and power imbalances between disputants. These costs are all reasons enough - in themselves - to be concerned about these wide-ranging trends. However, my main concern - and the driving concern behind this article - is the potential negative impact that the privatization of public dispute resolution processes has on systems of democratic governance.

Civil society is publicly regulated largely through legislation and adjudication. The adjudicative function - particularly in the context of the post-WW II welfare state - is clearly a central pillar of our processes of government. To the extent that we are actively privatizing how we do adjudication, we are in effect actively privatizing a large part of the way we govern ourselves in modern democracies. Unlike the benefits of privatization, about which people have been actively talking for some time, there is comparatively very little discussion or debate about the costs of privatizing our civil justice system. As one commentator has recently noted, although the move to privatize the justice system and its results are being "recently discovered," they are certainly "still not understood."1

\footnotetext{
${ }^{1}$ Tracy Walters McCormack, “Privatizing the Justice System” (2006) 25 Rev. of Lit. 735 at pt. i ["Privatizing the Justice System”].
} 
This lack of understanding is of particular concern given the ongoing and significant institutional reforms that are occurring in our justice system and the fundamental public interest values that are stake.

In seeking to address this concern, this article focuses on three parts of the justice system: the civil justice system, the administrative law system, and non-administrative-based legislative initiatives - typically including arbitration statutes - that actively sanction the resolution of civil disputes outside of the public court and administrative law systems. ${ }^{2}$ It does not focus on privatizing initiatives in the criminal justice system. ${ }^{3}$

By focusing on these three elements of the justice system, this article in turn has three main goals. First, it seeks to bear witness to the modern and wide-ranging privatization initiatives that are currently defining the way we think about and resolve almost all civil disputes. Second, it seeks to articulate the benefits and costs of these initiatives, particularly including their negative impact on the way we publicly regulate ourselves in modern, democratic societies. Third, this article makes recommendations for future thinking about, and approaches to these initiatives. In so doing, it calls on jurists, civil justice system reformers, elected representatives and citizens to engage in a robust debate about all aspects of the privatization of civil justice, the future of which will have a fundamental impact on our public processes of democracy.

2 This article also touches on the entirely private system - including negotiation and mediation, etc. - to the extent that the private system is annexed directly through the public stream (either through the court system, the administrative system, or through legislative initiatives).

3 For commentary on alternative, privatizing criminal justice initiatives, specifically including plea-bargaining initiatives, see e.g. Joseph Di Luca, "Expedient McJustice or Principled Alternative Dispute Resolution? A Review of Plea Bargaining in Canada” (2005) 50 Crim. L.Q. 14. I am grateful to James Stribopoulos and Mary M. Birdsell for assistance on this criminal law point. For a general critique of restorative justice, see e.g. Annalise A. Acorn, Compulsory Compassion: A Critique of Restorative Justice (Vancouver: UBC Press, 2004). 


\section{BACKGROUND: THE “DEALERSHIP” CASE}

Before looking at what I mean by privatization and some of its representative processes, benefits and costs, I first set out the story of a case - the "Dealership" case - that has dramatically influenced my thinking and driven my concerns in this area of my civil justice research. The case is also useful for animating some of the issues and arguments that I make throughout this article. Because, in my previous career as a litigator, I was co-counsel on the case, I have an inside perspective on it. I also, for the same reason, am limited in what I can say both because of basic solicitor-client confidentiality obligations and also because of a strict confidentiality agreement. However, although I have changed and omitted some names and facts to comply with all of my professional, ethical and legal obligations, the case that I present below is a case that actually happened. And I know, based on my own previous litigation practice and my current research, that it certainly is not a unique case.

For almost 50 years John, who immigrated to the United States when he was very young, operated a dealership in the Midwestern United States. He sold merchandise made exclusively by one of the biggest and most familiar manufacturers in United States history (the "Manufacturer”). John was an extremely popular dealer who won sales awards in almost all categories. He was a true American success story. Late in his career John was asked - purportedly by the Manufacturer's computer services division's local representative (who John had known and dealt with for years) and as part of the overall obligations and expectations set out in his dealership agreement - to purchase a new computer system and computer services package. Doing (as he always did) what the computer representative suggested and what he understood to be what the Manufacturer required, John agreed to purchase - without doing any research or "comparison shopping" - the full computer system and a longterm service package (the "Contract”).

As it turned out, the computer representative did not work for the Manufacturer but rather for a newly-reorganized, separate and privatelyheld multinational corporation (the "Corporation"). Notwithstanding the change in corporate structure and ownership, however, the representative's uniform, business card and letterhead continued - as they always had - to

use the Manufacturer's logo. The computer system that the representative 
recommended (and that John purchased) was designed for a much bigger dealership (or series of dealerships) than what John operated. Further, the cost of the equipment and services was vastly higher than the cost of the same equipment and services found on the open market. Finally, there was no Manufacturer requirement under John's dealership agreement to purchase the equipment or services. Put simply, the Corporation, relying on John's good faith, history of service, relationship with the representative and virtually blind loyalty to the Manufacturer, sold John an incredibly overpriced computer system and unreasonably lengthy service package that he did not need (or in fact want).

Subsequently, when John discovered the truth about the Corporation, the computer equipment and the service package, he decided to stop further payments and seek to resolve the matter with the Manufacturer and the Corporation. Because of the separate ownership structure of the Corporation, the Manufacturer wanted nothing to do with the dispute. The Corporation, for its part, was not willing to make any concessions. Further, based on the clear wording of the Contract and on John's refusal to pay, the Corporation proceeded to take legal action. Because the Contract provided that “all disputes" arising under the Contract were to be resolved pursuant to the commercial arbitration rules of a major American arbitration association, the Corporation initiated arbitration proceedings against John.

The Corporation's claim was simple: John should make the payments owed under the Contract. John, in his defense and counterclaim, argued that, in a nutshell, because the costs of the system and services were not only unreasonably high but were based on what amounted to at least a contract of adhesion if not fraud, the Contract should be set aside and he should be compensated for his losses (the payments that he had made to that date under the Contract). ${ }^{4}$ After a week-long hearing, the arbitrator found for the Corporation and dismissed John's counter-claim. Notwithstanding several years of preparation, volumes of documentary discovery and weeks of depositions, the

\footnotetext{
4 An animating (and aggravating) factor for John's defence and counter-claim was the fact that, given the system's incompatibility for a smaller dealership the size of John's, it did not function as advertised (or really at all).
} 
arbitrator - consistent with the arbitration association's practice, rules and guidelines - provided no oral or written reasons at all for his judgment. And because of the terms of the Contract, John essentially had no right of appeal.

Reasonable people can always disagree - particularly in hindsight - as to what the correct result should have been in a given case. While I am convinced that the arbitrator in the Dealership case got it wrong, I do not think that he acted in bad faith. However, as I discuss later in this article, $^{5}$ I am strongly of the view that the business practices of the Corporation that led to the dispute were at least unfairly aggressive, were likely pursued - at least by some - in bad faith, were part of a systematic and nation-wide approach of the Corporation to target similarly situated dealers through deceptive business practices and, as a result, likely amounted to fraud. Further, in addition to the questionable conduct on the part of the Corporation, I know - as I also discuss later in this article ${ }^{6}-$ that the lawyers for the Corporation acted on numerous occasions unprofessionally and in bad faith.

Unfortunately, the private dispute resolution system in which we were working - state-sanctioned commercial arbitration - did not provide the tools by which such conduct on the part of either the Corporation or its lawyers could be properly discovered, made public, prohibited or sanctioned. Part of the reason, as is discussed further below, ${ }^{7}$ was the system's lack of meaningful procedural safeguards. The more significant reason, in my view, was the curtain of secrecy - provided for by strategically drafted wide-ranging confidentiality provisions - that shielded the systematically suspect conduct of the Corporation and its lawyers in our proceeding, and in all of the similar proceedings about which we knew but could do nothing about. It is to these types of privacy issues - and their related impact both on individual litigants and on the regulation of large sectors of society - to which I now turn.

\footnotetext{
${ }^{5}$ See infra part IX.

${ }^{6}$ Ibid.

${ }^{7}$ Ibid.
} 


\section{Privatization}

What do I mean by privatization? ${ }^{8}$ Privatization, as I will further discuss and develop throughout this article, means four (often related) things.

\section{A. JURISDICTIONAL PREFERENCES}

First, as a matter of jurisdiction, it means a preference for moving away from directly state-funded and state-run dispute resolution forums (e.g. civil courts or administrative tribunals) and toward typically privately-organized and privately-funded initiatives (e.g. private mediation chambers or arbitration regimes, etc.). This preference has led to what the Supreme Court of Canada has recently described as the creation of a "private justice system." It was also this form of privatization that was specifically at issue in the Dealership case: a forum selection clause in the Corporation's standard form Contract that ousted the jurisdiction of a court in favour of a private arbitration regime. ${ }^{10}$

\footnotetext{
${ }^{8}$ The privatization of civil justice is a topic that I have been specifically thinking about for some time and in which - given its fundamental procedural and normative implications - I continue to be interested. For some preliminary thinking on the topic, see e.g. Trevor C. W. Farrow, "Privatizing our Public Civil Justice System” (2006) 9 News \& Views on Civil Justice Reform 16, online: Canadian Forum on Civil Justice (CFCJ) <http://www.cfcj-fcjc.org/issue_9/CFCJ\%20(eng)\%20spring\%202006Privatizing.pdf $>$ ["Privatizing our Public Civil Justice System"], Trevor C. W. Farrow, "Re-Framing the Sharia Arbitration Debate" (2006) 15:2 Const. Forum Const. 79 ["ReFraming the Sharia Arbitration Debate"], Trevor C. W. Farrow, "The rule of law in developing countries is not just about courts” 26:31 The Lawyers Weekly (15 December 2006) (QL) [“The rule of law in developing countries is not just about courts”]. For some earlier comments, see Trevor C. W. Farrow, "Dispute Resolution, Access to Civil Justice and Legal Education” (2005) 42 Alta. L. Rev. 741 at 797-798 [“Dispute Resolution, Access to Civil Justice and Legal Education”]. See further Andrew Pirie, "Critiques of Settlement Advocacy” [“Critiques of Settlement Advocacy”] in Colleen M. Hanycz, Trevor C. W. Farrow and Frederick H. Zemans, The Theory and Practice of Representative Negotiation (Toronto: Emond Montgomery, 2008) at c. 11.

${ }^{9}$ Dell Computer Corp. v. Union des consommateurs, 2007 SCC 34, at para. 132 (reference omitted).

${ }^{10}$ Supra part II.
} 
Further, even within the public court system, there is a continued and increasing preference - expressly promoted by all stakeholders in the public civil dispute resolution system, including governments, courts and judges, lawyers, law societies, bar associations, law schools and clients for using private processes such as mandatory mediation regimes, judicial dispute resolution initiatives, settlement negotiations, etc., rather than the publicly-scrutinized full trial process.

\section{B. PRIVACY}

Second, as an information flow matter, privatization means moving disputes out of the public eye and into confidential, or at least largely private, settings. This aspect of privatization is part of the confidential processes in the public justice and administrative law systems (e.g. mandatory or voluntary mediation programs that increasingly form parts of both of those public systems). It is also a defining badge of private processes (e.g. commercial arbitration). Again, this aspect of privatization was at issue in the Dealership case: it was clearly the motivation of the Corporation to keep its affairs out of the eyes of the public. ${ }^{11}$

\section{LAWYERS: PROFESSIONALISM AND COMMERCIALISM}

Third, the active involvement of lawyers in the settlement process through various ADR regimes including court-annexed judicial dispute resolution processes and private settlement negotiations has become an important and relatively newly-recognized aspect of lawyers' professional responsibility obligations. Further, as a commercial matter, privatization at the same time recognizes the increased role for private, for-profit actors in the resolution of civil disputes. The number of lawyers and other professionals advertising an expertise in all ADR areas and processes continues to expand in Canada.

\section{CIVIL SOCIETY}

Fourth, as a social relations matter, privatization downloads the resolution of civil disputes from the public and collective levels of civil

\footnotetext{
${ }^{11}$ Ibid.
} 
society to more intimate and private spheres: the family, religious communities, the boardroom, the web, etc. ${ }^{12}$

\section{E. OVERALL REsult}

All of these understandings of privatization animate the various arguments that I make in this article. The overall result of these four meanings of privatization - taken together - is a systematic increase in the number of all kinds of disputes, including commercial manufacturing and service disputes, employment disputes, pay-equity disputes, police complaints, family disputes, human rights complaints, etc., that are being decided in private, using private adjudicators, with no public access, and without necessarily any of the procedural safeguards that are typically provided for in our public court or tribunal systems. ${ }^{13}$ These forms of privatization are encouraged, mandated and/or happening in all sectors and at all levels of the civil justice system, the administrative system and through statutorily-encouraged private dispute resolution initiatives.

\section{GoVERnMENT PREFERENCES For Privatization}

As a starting point, it is important to recognize that the introduction into, and encouragement of privatization initiatives in these three levels of the civil dispute resolution system is part of a larger - federal and provincial - government strategy to encourage the privatization of dispute resolution in relation essentially to all activities in which the government is involved or regarding which it has some direct or indirect connection.

At the federal level, for example, Canada's Dispute Resolution Service (DRS) was established in 1992, under the watch of the Department of Justice, actively to promote ADR and related services. According to its materials:

...DRS...is devoted to the prevention and management of disputes. Our mandate is to serve as a leading centre of DR

\footnotetext{
${ }^{12}$ For a useful treatment of changes in public and private space, see Law Commission of Canada, ed., New Perspectives on the Public-Private Divide (Vancouver: UBC Press, 2003).

${ }^{13}$ See "Re-Framing the Sharia Arbitration Debate”, supra note 8.
} 
excellence in Canada. Our role is to promote a greater understanding of DR and assist in the integration of DR into the policies, operations and practices of departments and agencies of the Government of Canada, Crown Corporations, federal tribunals and administrative agencies, and federally constituted courts. ${ }^{14}$

At the provincial level, similar initiatives have been pursued. In British Columbia, for example, the Government - through the Ministry of Attorney General - has developed an active policy of ADR promotion through the 1996 creation of the Dispute Resolution Office (DRO). According to its public materials:

The Ministry of Attorney General's...[DRO] develops and promotes non-adversarial dispute resolution options within the justice system and government. Options such as mediation encourage early settlement of disputes and are less expensive than processes used in the formal court system. $^{15}$

The policy considerations behind these initiatives are animated by the general reform trends and research projects carried out over the past several decades in various Commonwealth countries - including Canada ${ }^{16}$

\footnotetext{
${ }^{14}$ Department of Justice Canada, "DRS Programs and Services” (last updated: 24 April 2007), online: Government of Canada $<$ http://canada.justice.gc.ca/en/ps/drs/drs_programs.html>.

${ }^{15}$ B.C. Ministry of Attorney General, "DRO”, online: B.C. Government $<$ http://www.ag.gov.bc.ca/dro/>.

${ }^{16}$ The B.C. Ministry of Attorney General specifies that the DRO initiatives "are largely outcomes of considerable research and study carried out in the 1990's by organizations and professional groups across common law jurisdictions, for example, the Canadian Bar Association's Systems of Civil Justice Task Force Report, Lord Wolff's Report on Access to Justice, England, and Managing Justice: A Review of the Federal Civil Justice System, a report published by the Australian Law Reform Commission.” See ibid. at
} 
- toward simplified and privatized ADR initiatives across all aspects of the public civil dispute resolution spectrum. Again according to the B.C. Ministry of Attorney General:

There is considerable interest in resolving civil disputes outside of the formal court system. Options such as mediation are being employed by the courts, administrative tribunals, and ministries and agencies of the Government of BC to provide people with viable dispute resolution processes...

The Ministry of Attorney General has adopted an ADR Policy, signaling its commitment to a justice and conflict resolution environment which includes a wide range of dispute resolution options. In 1996, the ministry established the...DRO...to develop and implement dispute resolution options in the court system and in government.

Since 1996, the DRO has worked with a number of government ministries, boards, agencies and commissions to design and help implement [] dispute resolution processes. It has also helped organizations consider ways to improve existing processes to make them more efficient and effective. ${ }^{17}$

The goals of these sorts of initiatives are clear. For example, the Ministry of Attorney General states its intention to, among other things:

Further develop the ADR policy to broaden and encourage the application of dispute resolution options through:

\footnotetext{
“Alternative Dispute Resolution Policy and Design”, online: B.C. Government $<$ http://www.ag.gov.bc.ca/dro/policy-design/index.htm>. Some of these reform initiatives are cited and discussed further in this article. See e.g. infra note 32 and surrounding text.

${ }^{17}$ B.C. Ministry of Attorney General, DRO, “Alternative Dispute Resolution Policy and Design”, online: B.C. Government <http://www.ag.gov.bc.ca/dro/policydesign/index.htm>.
} 
a) continuing consultation with dispute resolution stakeholders and advocates;

b) promoting the use of alternative dispute resolution options among all ministries and agencies of government;

c) promoting the use of alternative dispute resolution techniques in neighbourhood or community disputes;

d) identifying and removing barriers to the understanding and use of alternative dispute resolution options;

e) supporting multi-party alternative dispute resolution processes such as land use planning, aboriginal treaty. ${ }^{18}$

Three key aspects of these sorts of federal and provincial government dispute resolution preferences include encouraging the privatization of civil dispute resolution in the civil justice system (discussed immediately below), the administrative system (discussed infra at part VI), and through provincial and federal arbitration and other enabling dispute resolution legislative initiatives (discussed infra at part VII).

\section{Civil Justice System}

The first part of the public civil dispute resolution system on which I focus in this article is the civil justice system, with a primary focus on the provincial superior civil courts.

\section{A. SUPERIOR COURTS}

Modern provincial superior courts of record throughout Canada enjoy the plenary jurisdiction, power and authority at law and in equity

${ }^{18}$ Ibid. at "Alternative Dispute Resolution Policy and Design: Policy Statement, Objectives" (objective 12), online: B.C. Government $<$ http://www.ag.gov.bc.ca/dro/policy-design/statement.htm>. 
that were historically exercised by the courts of common law and equity in England and subsequently in early Canada. ${ }^{19}$ This plenary jurisdiction provides courts with "all the powers that are necessary to do justice" (typically within the province ${ }^{20}$ ), which is a jurisdiction that is "unlimited and unrestricted in substantive law in civil matters." 21 This jurisdiction is limited only "where provided specifically to the contrary" by a "special law".22

This adjudicative regime provides for a publicly funded dispute resolution system that is - at least in theory ${ }^{23}$ - open to all parties and to all disputes. As summarized by John Godfrey Spragge (when advocating - before becoming a Chancellor of Upper Canada - for an early court of equity in Upper Canada), this system, which is "built upon precedent and

${ }^{19}$ See e.g. Courts of Justice Act, R.S.O. 1990, c. C.43, s. 11(2). See also Constitution Act, 1867, 30 \& 31 Victoria, c. 3 (U.K.), ss. 92(13)-(14), 96-100, 129.

${ }^{20}$ For rules regarding the commencement of proceedings within and without a province, see e.g. Ontario Rules of Civil Procedure, R.R.O. 1990, Reg. 194, as amended, rr. 16-17. For a discussion of the extraterritorial application of a provincial superior court's jurisdiction, see e.g. Janet Walker gen. ed. et al., The Civil Litigation Process: Cases and Materials, 6th ed. (Toronto: Emond Montgomery, 2005) [The Civil Litigation Process] at 249-271.

${ }^{21} 80$ Wellesley St. East Ltd. v. Fundy Bay Builders Ltd. et. al., [1972] 2 O.R. 280, Brooke J.A. (CA) (QL). See also Board v. Board (1919), 48 D.L.R. 13 (P.C.). For a brief history of the courts in Canada, see The Civil Litigation Process, supra note 20 at 18-44.

${ }^{22} 80$ Wellesley St. East Ltd. v. Fundy Bay Builders Ltd. et. al., supra note 21. For contrary jurisdictional legislation, see e.g. Courts of Justice Act, supra note 19 at s. 148 (recognizing the jurisdiction of the Federal Court of Canada).

${ }^{23}$ Of course there is overwhelming evidence of the lack of access to courts that many, if not most, Canadians experience today. And this lack of access is one of the reasons for the development of alternative models of civil dispute resolution, as discussed further below (infra note 126 and surrounding text). For a further discussion, see "Dispute Resolution, Access to Civil Justice and Legal Education”, supra note 8. And there is also evidence that the court system, although in theory open, did not always provide for just and progressive decisions and policies for all members of society. For a discussion of some of these issues, see W. Bogart, Courts and Country (Toronto: Oxford University Press, 1994) 107-124 [Courts and Country], cited in The Civil Litigation Process, supra note 20 at 36-44. 
authority", is established by the state "so that a man may, with reasonable certainty, know what the law is, and govern himself accordingly". 24 To bring into effect this regulatory influence of this system, court orders are entered in the entry book of the provincial registrar, ${ }^{25}$ precedents are published, and "all court hearings shall be open to the public."26 Taken together, this regime provides an adjudication tool that has played an "instrumental" role in the "historical development of Canada" and in "economic growth",27 and that continues to be "an essential component of our democratic form of government."28

\section{B. Privatization Through ADR AND Other Reforms}

Almost since their inception, concerns over the high cost, low efficiency and imperfect access to these public court systems have led to continued reform efforts. In the United States, for example, according to an 1850 proposal, reforms to the civil procedure system of New York were "to make legal proceedings more intelligible, more certain, more speedy, and less expensive."29 Similar wording is found in most modern reform efforts as well, which really hit their stride in the 1970s in the United

${ }^{24}$ From a pamphlet by John Godfrey Spragge (untitled and undated) in The Civil Litigation Process, supra note 20 at 20.

${ }^{25}$ See e.g. Ontario Rules of Civil Procedure, supra note 20 at r. 59.05.

${ }^{26}$ See e.g. Courts of Justice Act, supra note 19 at s. 135(1) (subject to the limited exceptions provided for in s. 135(2)).

27 M. H. Ogilvie, "Recent Developments in Canadian Law: Legal History" (1987) 19 Ottawa L. Rev. 225 at 237, 239 ["Recent Developments in Canadian Law: Legal History”].

${ }^{28}$ Wayne D. Brazil, "Hosting Mediations as a Representative of the System of Civil Justice" (2007) 22 Ohio St. J. Disp. Resol. 227 at 241. For comments that these progressive values were more present in American than in Canadian courts in the 1800s and early 1900s, see "Recent Developments in Canadian Law: Legal History", supra note 27 at 250-251. See also Courts and Country, supra note 23. Regardless, the influence of the courts on the development of economic and social relations in Canada, particularly over the past 25 years, is undeniable.

29 Arphaxed Loomis, David Graham and David Dudley Field, "Commission of Practice \& Pleadings Code Civ. Proc.: Report” (N.Y., iii, 1850) (HeinOnline). 
States in the context of widespread dissatisfaction with the overall administration of civil justice. Those reform initiatives - including for example the 1976 Pound Conference and discussions by Frank Sander and his colleagues at Harvard Law School ${ }^{30}$ about a multi-door courthouse continue to drive modern thinking about ways of making the delivery of civil justice more accessible and efficient. ${ }^{31}$

Reform initiatives across Canada have followed their American counterparts. In 1996, at the national level, the Canadian Bar Association engaged in a wide-ranging and influential review of the delivery of civil justice in Canada. Numerous observations and recommendations, made in that report, have led to significant and ongoing reform initiatives in this country. ${ }^{32}$

${ }^{30}$ For comment on the influence of these individuals on modern dispute resolution reforms, see e.g. Jay Folberg, "A Mediation Overview: History and Dimensions of Practice” in (1983) 1 Mediation Q., c. 1, p. 3 at 7. For some of their ideas, see e.g. Frank E. A. Sander, "Varieties of Dispute Processing" in A. Leo Levin and Russell R. Wheeler, eds., The Pound Conference: Perspectives on Justice in the Future (St. Paul: West Publishing, 1979) 65.

${ }^{31}$ For brief discussions of ADR's modern history, see e.g. "Dispute Resolution, Access to Civil Justice and Legal Education”, supra note 8 at pt. II.A-C, Trevor C. W. Farrow, “Thinking About Dispute Resolution”, Review Essay (2003) 41 Alta. L. Rev. 559 at pt. I. See further e.g. Warren E. Burger, "Isn't There a Better Way?” (1982) 68 A.B.A. J. 274, Brian Dickson, "ADR, The Courts and The Judicial System: The Canadian Context" (1994) 28 L. Soc’y Gaz. 231 at 236, George W. Adams, Mediating Justice: Legal Dispute Negotiations (Toronto: CCH Canadian, 2003) at 12-15, D. Paul Emond, "Alternative Dispute Resolution: A Conceptual Overview” in D. Paul Emond, ed., Commercial Dispute Resolution: Alternatives to Litigation (Aurora, ON: Canada Law Book, 1989) 1 [“A Conceptual Overview”], "Critiques of Settlement Advocacy”, supra note 8 at 290292, Andrew Pirie, Alternative Dispute Resolution: Skills, Science, and the Law (Toronto: Irwin Law, 2000) at 1-33, Carrie Menkel-Meadow, "Introduction: What Will We Do When Adjudication Ends? A Brief Intellectual History of ADR" (1997) 44 UCLA L. Rev. 1613.

${ }^{32}$ See Canadian Bar Association (CBA), Task Force on Systems of Civil Justice, "Systems of Civil Justice Task Force Report” (Ottawa: CBA, 1996), online: CBA $<$ http://www.cba.org/CBA/pubs/pdf/systemscivil_tfreport.pdf> ["CBA Task Force Report"]. The CFCJ and others held two "Into the Future" conferences recently to discuss the "agenda for civil justice reform" coming out of the "CBA Task Force Report”. For useful papers and discussions from those conferences, see CFCJ, "Into the 
However, notwithstanding these significant initiatives, the same calls for reforms to address cost, speed and backlogs continue to be made. For example, in December 2006, former Ontario Chief Justice R. Roy McMurtry made the following comments:

In Ontario, it has been recognized for some years that our civil justice system is in a crisis...

I became a judge in 1991 and very quickly learned that the issue of access to civil justice would be the principal justice challenge for the foreseeable future. In 1995, as the Chief Justice of the Superior Court, I referred to the crisis and stated publicly that:

As well as the increasing cost, the system is labouring under the tremendous weight of a growing backlog of cases and a serious lack of adequate resources. Litigants must wait an inordinate length of time to resolve their civil disputes. Significant initiatives are absolutely essential if our court is to be able to provide timely and affordable justice to the citizens of this province.

Future - Conference Papers”, online CFCJ <http://cfcj-fcjc.org/publications/itfen.php\#1>. For a further discussion of the CBA initiatives, see "Dispute Resolution, Access to Civil Justice and Legal Education”, supra note 8 at pt. II.C. For useful sources for civil justice reform initiatives, see Margaret A. Shone, "Civil Justice Reform in Canada: 1996 to 2006 and Beyond” (December 2006), online: CFCJ <http://cfcjfcjc.org/docs/2006/shone-final-en.pdf> [“Civil Justice Reform in Canada: 1996 to 2006 and Beyond"], CFCJ, "Inventory of Reforms", online CFCJ <http://cfcjfcjc.org/news/?cat=2> (which includes reform initiatives in Canada from 1950-2007). For discussions of, and links to many of the civil justice reform initiatives discussed below, see CFCJ, “Civil Justice News”, online: CFCJ <http://cfcj-fcjc.org/news/?cat=2> ["Civil Justice News"]. This portion of this article is significantly influenced by those sources, discussions and links. 
Well, almost twelve years later, the crisis has deepened despite the best efforts of a lot of people, judges, lawyers and officials in the Ministry of the Attorney General. ${ }^{33}$

At the provincial and territorial levels, numerous efforts are being made to address the kinds of "crisis" that the former Chief Justice of Ontario described. Every superior court in Canada has been looking at ways of making civil dispute resolution processes more efficient and effective. $^{34}$ For example, the B.C. Justice Review Task Force recently released its "Effective and Affordable Civil Justice" report ${ }^{35}$ and proposed new rules of civil procedure. ${ }^{36}$ In Alberta, the Rules Project of the Alberta Law Reform Institute (ALRI) also recently released its proposed new rules of civil procedure. ${ }^{37}$ Ontario $^{38}$ and Nova Scotia ${ }^{39}$ are both currently

${ }^{33}$ The Honourable R. Roy McMurtry, CFCJ, Civil Justice Reform Conference: Phase II, Remarks (7 December 2006) at 3-4, online: CFCJ <http://cfcjfcjc.org/docs/2006/mcmurtry-en.pdf> [“McMurtry Remarks”].

${ }^{34}$ For a very useful and comprehensive study of, and recommendations regarding, civil justice reform initiatives across Canada, see "Civil Justice Reform in Canada: 1996 to 2006 and Beyond”, supra note 32. Of course, similar initiatives are being experimented with in courts not only in Canada but also in most countries around the world. For the present purpose, however, this part of this article will primarily limit itself to reform initiatives in Canadian courts.

${ }^{35}$ Civil Justice Reform Working Group to the Justice Review Task Force, "Effective and Affordable Civil Justice” (November 2006), online: B.C. Justice Review Task Force $<$ http://www.bcjusticereview.org/working_groups/civil_justice/cjrwg_report_11_06.pdf>

${ }^{36}$ B.C. Justice Review Task Force, "Proposed New Rules of Civil Procedure of the British Columbia Supreme Court” (23 July 2007), online: B.C. Justice Review Task Force, <http://www.bcjusticereviewforum.ca/civilrules/downloads/conceptDraft.pdf >. For earlier B.C. reform initiatives, see e.g. Hon. E. N. Hughes, Access to Justice: Report of the Justice Reform Committee (Victoria: Ministry of Attorney General, 1988).

${ }^{37}$ ALRI, “Alberta Rules of Court”, Test Draft 3 (February 2007), online: University of Alberta, Faculty of Law $<$ http://www.law.ualberta.ca/alri/docs/ALRIdraft\%20Rules\%20of\%20Court\%20TD3.pdf $>$.

${ }^{38}$ See Hon. Coulter A. Osborne, Q.C., “Civil Justice Reform Project” (November 2007), online: Ontario Government $<$ http://www.attorneygeneral.jus.gov.on.ca/english/about/pubs/cjrp/>. For earlier Ontario 
pursuing significant civil justice reform projects. Québec, several years ago, enacted significant changes to its Code of Civil Procedure. ${ }^{40}$ And other jurisdictions are similarly engaged in significant reform initiatives. ${ }^{41}$

Because the main concerns that underlie these reform efforts often include - as the former Chief Justice of Ontario identified - speed and cost, many of the potential solutions involve ADR and ADR-related initiatives. As McMurtry J. stated, in these types of reform initiatives, "we recognize that ADR is now firmly entrenched." ${ }^{\text {"42 }}$ It is these kinds of ADR reforms that form essential elements of the privatization trends that I am discussing in this article. For example, court-annexed mediation, ${ }^{43}$ judge-

reform initiatives, see e.g. Zuber Commission Report: Ontario, "Report of Ontario Courts Inquiry”, by T. G. Zuber (Toronto: Ontario Ministry of Attorney General, 1987), Law Society of Upper Canada (LSUC), "Alternatives - The Report of the Dispute Resolution Subcommittee” (Toronto: LSUC, 1993), Ontario Civil Justice Review, "Civil Justice Review: Supplemental and Final Report” (Toronto: Ontario Civil Justice Review, 1996).

${ }^{39}$ See e.g. The Court of Nova Scotia, Civil Procedure Rules Nova Scotia: Rules Revision Project, online: The Court of Nova Scotia $<$ http://www.courts.ns.ca/rules_revision/revision.htm>.

${ }^{40}$ R.S.Q., c. C-25 (updated to 1 September 2007), online: Éditeur official du Québec $<$ http://www2.publicationsduquebec.gouv.qc.ca/dynamicSearch/telecharge.php?type=2\& file=/C_25/C25_A.HTM >. For commentary on Québec’s civil justice reform process, see Justice Québec, "Reform of Civil Procedure”, online: Justice Québec $<$ http://www.justice.gouv.qc.ca/english/ministere/dossiers/crpc/crpc-a.htm>.

${ }^{41}$ See e.g. Yukon Government, News Release, "Government Modernizing Yukon Courts By Amending Three Acts" (31 October 2005), online: Yukon Government <http://www.gov.yk.ca/news/2005/05-284.html>. See earlier Manitoba, Civil Justice Review Task Force, "Manitoba Civil Justice Review Task Force Report” (Winnipeg: Department of Justice, 1996) (Chair: David Newman). Many of these reform initiatives discussed in this note and notes 34-40 and surrounding text are also discussed briefly in "Dispute Resolution, Access to Civil Justice and Legal Education”, supra note 8 at n. 46 and surrounding text. See also CFCJ, "Civil Justice News”, supra note 32.

42 “McMurtry Remarks”, supra note 33 at 7.

${ }^{43}$ See e.g. Court of Queen's Bench of Alberta, Civil Practice Note No. 11, "Court Annexed Mediation” (effective 1 September 2004), online: Alberta Courts $<$ http://www.albertacourts.ab.ca/qb/practicenotes/civil/pn11CourtAnnexedMediation.pdf >, Saskatchewan, Queen's Bench Act, 1998, S.S. 1998, c. Q-1.01, s. 42 ("Mediation”), Ontario Rules of Civil Procedure, supra note 25 at r. 24.1 ("Mandatory Mediation”). 
assisted $^{44}$ and judicial dispute resolution programs, ${ }^{45}$ specific familyrelated mediation services in superior courts, ${ }^{46}$ notices to mediate, ${ }^{47}$ etc., all directly provide for non-trial-based, typically private alternative processes for the resolution of court-based civil disputes.

The motivation behind these court-connected ADR initiatives is clear: "to reduce cost and delay in litigation and facilitate the early and fair resolution of disputes., ${ }^{48}$ Further, case management ${ }^{49}$ and pre-trial conference $^{50}$ initiatives provide judges with other robust tools for the encouragement and facilitation of private settlements out of court (or at least out of the scrutiny of the public court room). ${ }^{51}$ Additionally,

\footnotetext{
${ }^{44}$ See e.g. Québec’s judge-assisted “Settlement Conference” initiative: Justice Québec, "Settlement Conference of the Superior Court of Québec", online:

$<$ http://www.justice.gouv.qc.ca/english/publications/generale/amiable-cs-a.htm>.

${ }^{45}$ For a discussion of the Judicial Dispute Resolution program in Alberta's Court of Queen's Bench, see the Honourable Justice John A. Agrios, “A Handbook on Judicial Dispute Resolution for Canadian Lawyers”, Version 1.1 (January 2004), online: CBA Alberta <http://www.cba.org/alberta/PDF/JDR\%20Handbook.pdf>.

${ }^{46}$ See e.g. Ontario Ministry of the Attorney General, "Family Mediation Services", online: Ontario Government $<$ http://www.attorneygeneral.jus.gov.on.ca/english/family/mediation.asp>.

${ }^{47}$ See e.g. British Columbia Dispute Resolution Office, "Bulletin: Notice to Mediate, (General) Regulation” (June 2002), online: British Columbia Government <http://www.ag.gov.bc.ca/dro/publications/bulletins/general.htm>.

${ }^{48}$ Ontario Rules of Civil Procedure, supra note 25 at r. 24.1.01. For judicial commentary on the purpose of R. 24.1, see e.g. Hagel v. Giles (2006), 80 O.R. (3d) 170 at paras. 27, 34 (S.C.J.), aff'd (2006), 82 O.R. (3d) 470. See also Dicaro v. Wong, [2001] O.J. No. 347 (Master). As is clear from the case law, courts are slow to exempt parties from these mandatory ADR requirements. See e.g. O. (G.) v. H. (C.D.) (2000), 50 O.R. (3d) 82 (S.C.J.), discussed further infra at notes 165-166 and surrounding text.
}

${ }^{49}$ See e.g. Ontario Rules of Civil Procedure, supra note 25 at rr. 77-78.

${ }^{50}$ See e.g. ibid. at r. 50.

${ }^{51}$ See e.g. ibid. at rr. 77.13(5)-(6), both of which sub-rules provide for the referral of "any issue for alternative dispute resolution”. 
incentives built into typical Canadian fee-shifting cost rules provide parties with added legislatively-sanctioned court-based encouragement for private, non-trial-based settlements. ${ }^{52}$ Taken together, these are the sorts of civil justice tools that make up "all of the efforts over many years to encourage settlement between parties."53

\section{OTHER COURTS}

Courts of statutory jurisdiction in Canada are also experimenting with significant reform initiatives, many of which - seeking the same reform goals of reduced cost and increased speed and efficiency - result in the privatization of their processes. Small claims courts, for example, which have played an important role in the state's goal of providing a just, cost-effective and accessible public venue for the resolution of many dayto-day disputes in society, ${ }^{54}$ have for some years been experimenting with and implementing various alternative private process options. Many of these initiatives include various case management and other ADR

${ }^{52}$ See e.g. ibid. at r. 49.

${ }^{53}$ Hagel v. Giles, supra note 48 at para. 34, D. J. Power J.

54 Small claims courts, according to Marvin Zuker, “originated in response to a perception that the complex and technical regular civil procedure made it virtually impossible for wage earners and small businessmen to use the court system to collect wages or accounts which they were owed." Marvin A. Zuker, Small Claims Court Practice (Toronto: Carswell, 1998) 2-3 [Small Claims Court Practice], in The Civil Litigation Process, supra note 20 at 27. Key to the process is an effort to reduce delay by simplifying the process by which these disputes get resolved. Badges of the small claims court system include less of a need for litigants to be represented by lawyers, more interventionist judges (able to assist the parties when necessary to narrow the issues and move through the trial process), relaxed rules of evidence and simplified rules of trial procedure. See e.g. Small Claims Court Rules, O. Reg. 258/98, as amended. See also Ontario Ministry of the Attorney General, "Small Claims Court Guides to Procedures", online: Ontario Government <http://www.attorneygeneral.jus.gov.on.ca/english/courts/guides/>. In sum, according to Zuker, the "crux of the small claims procedure is informality and simplicity". Small Claims Court Practice, supra. Informality, however, does not equal privacy. The traditional small claims court model still contemplates an open, public dispute resolution process. 
(typically mediation-oriented) regimes. ${ }^{55}$ Other provincial inferior court initiatives include mediation and case management programs, often in family law cases. ${ }^{56}$ Similarly, at the federal court level, case management and ADR - primarily through the court's "case management and dispute resolution services" program ${ }^{57}$ - have been implemented for some years now and are being actively pursued as tools to reduce backlog and eliminate "dead wood" proceedings from the court's docket. ${ }^{58}$

\section{JUdGes, LAW SOCIETIES, BAR AsSOCIATIONS AND LAW SCHOOLS}

In addition to government preferences ${ }^{59}$ that have led to these various court-based reform initiatives, there are numerous other players in the civil justice system that are also actively participating in and promoting the use of alternative - private - processes for resolving civil disputes.

One of the most influential voices in this group of civil justice participants is that of judges. Increasingly the courts are actively speaking up and encouraging parties to make use of out-of-court settlement processes, including mediation, negotiation (either directly or through lawyers), other ADR settlement processes and cost-based settlement

\footnotetext{
${ }^{55}$ See e.g. Alberta Provincial Court: "Mediation and the Provincial Court", online: Alberta Courts $<$ http://www.albertacourts.ab.ca/pc/civil/publication/mediation_and_the_provincial_court .htm>, British Columbia Dispute Resolution Office, "Bulletin: Court Mediation Program" (June 2002), online: <http://www.ag.gov.bc.ca/dro/publications/bulletins/courtmediation.htm>. See generally "Civil Justice Reform in Canada: 1996 to 2006 and Beyond”, supra note 32 at 31-32, The Civil Litigation Process, supra note 20 at 26-30.

${ }^{56}$ See e.g. Ontario Family Law Rules, O. Reg. 439/07, s. 40.

${ }^{57}$ See Federal Court Rules, SOR/2004-283, pt. 9, rr. 380-391.

${ }^{58}$ The Honourable Allan Lutfy, Swearing-in Ceremony, Associate Chief Justice (as he then was) (7 January 2000), online: Federal Court of Canada <http://cas-ncr-nter03.cassatj.gc.ca/portal/page/portal/fc_cf_en/Speech>.

${ }^{59}$ Discussed supra part IV.
} 


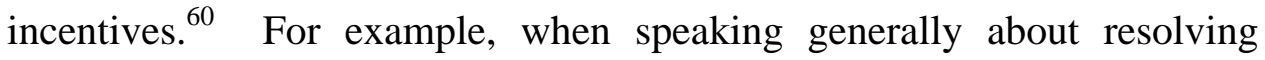
disputes out of court, Armstrong J.A. of the Ontario Court of Appeal stated that: "Settlement discussion is something which pervades, and should pervade, almost every lawsuit."61 Similarly, Gonthier J. - when speaking about the modern, expansive role of the advocate - stated that:

60 Settlement through private means has become the norm, and not the exception, in the civil justice system. Put simply: almost all disputes settle. According to one source, the "vast majority [of cases]... are...resolved through a variety of related processes that have come to be grouped under the broad heading of 'alternative dispute resolution..."' The Civil Litigation Process, supra note 20 at 525. Further, as Paul Emond has noted, "the vast majority (95\% to 98\%) of disputes are resolved through negotiation and not adjudication”. See “A Conceptual Overview”, supra note 31 at 3. For further discussions of these trends, see e.g. Julie Macfarlane, “Why Do People Settle?” (2001) 46 McGill L.J. 663 at 665, ALRI, Consultation Memorandum No. 12.6, "Promoting Early Resolution of Disputes by Settlement” (Edmonton: ALRI, July 2003), online: ALRI Homepage <http://www.law.ualberta.ca/alri/docs/cm12-6.pdf> at 8, n. 17, which indicates that the "current ratio of trials to filings in...Canadian and foreign jurisdictions" is "less tha[n] 2\%." For a further discussion of these comments, see "Dispute Resolution, Access to Civil Justice and Legal Education”, supra note 8 at n. 43. Similarly, according to the Australian Law Reform Commission (ALRC), “As the empirical data...confirms, the vast majority of civil disputes commenced within the federal court and tribunal system are concluded by means other than formal adjudication... They are settled by negotiation or through other dispute resolution mechanisms (such as mediation, conciliation or arbitration)..." ALRC, "Review of the Federal Civil Justice System”, Discussion Paper 62 (1999) at c. 3, para. 3.40 [footnotes omitted], online: ALRC $<$ http://www.austlii.edu.au/au/other/alrc/publications/dp/62/>, discussed further in “Dispute Resolution, Access to Civil Justice and Legal Education”, supra note 8 at n. 44 and surrounding text. Estimates as to the way and at what stage of the process these disputes are resolved vary and are not precise. However, at least one Ontario report found that "approximately 55\% of cases commenced never proceed to the point where a statement of defence is filed" and the "remaining 45\% of the case load proceeds through various additional stages of litigation, with the vast majority settling at some point between the pleading stage and the eve or morning of trial.” Ontario Civil Justice Review, First Report (March 1995), online: Ontario Ministry of the Attorney General <http://www.attorneygeneral.jus.gov.on.ca/english/about/pubs/cjr/> at c. 13, n. 47 and surrounding text, also in The Civil Litigation Process, supra note 20 at 529 (footnote omitted).

${ }^{61}$ Ristimaki v. Cooper (2006), 79 O.R. (3d) 648 at para. 76 (C.A.) (QL). For other judicial comments regarding settlement encouragement, see e.g. Heritage Duty Free Shop Inc. v. Canada (Attorney General), [2003] B.C.J. No. 1208 at paras. 17-18 (S.C.) (QL), aff'd [2005] B.C.J. No. 670 (C.A.), Guelph Centre Partners Inc. v. Guelph Storm Ltd., [2005] O.J. No. 458 at para. 10 (S.C.J.) (QL). See also the discussion of settlement in 
[C]ontrary to popular belief, not only will a good advocate not foment dissension and promote disputes between parties, he will seek to reconcile opposing interests in order to avoid the ultimate confrontation of a trial. He will be called on to play the role of moderator, negotiator and conciliator. Indeed, it is his duty to facilitate a rapid solution to disputes and to avoid fruitless or frivolous actions...Thus, whenever it is appropriate to do so, the advocate must discuss alternative dispute resolution methods (mediation, conciliation and arbitration) with his client, and must properly advise the client regarding the benefits of settling disputes. He may also hold discussions with the opposing party and negotiate a resolution of the dispute between the parties. ${ }^{62}$

Taking the spirit of these statements seriously, lawyers are increasingly espousing the merits of ADR with their clients. This opening up to settlement alternatives is occurring at one level as a practical business-savvy - matter. Lawyers are realizing the increased benefits for their clients in using ADR tools in terms of cost and time savings. They are also increasingly discovering their own economic opportunities and benefits that can result from expanding their practice skills to include ADR tools.

At another - professional - level, lawyers' warming up to alternative, private settlement tools is also occurring as a matter of professional conduct. For example, according to the Legal Ethics Handbook of the Nova Scotia Barristers' Society,

A lawyer has a duty to advise and encourage the client to settle a case rather than commence or continue legal

Trevor C. W. Farrow, "Ethics in Advocacy" in Alice Woolley, Brent Cotter and John Law, eds., Professional Responsibility in Canada (Toronto: LexisNexis, forthcoming). See further Rogacki v. Belz (2003), 67 O.R. (3d) 330 (C.A.), Rudd v. Trossacs Investments Inc. (2006), 79 O.R. (3d) 687 (Div. Ct.).

${ }^{62}$ Fortin v. Chrétien, [2001] 2 S.C.R. 500 at para. 53. 
proceedings where the case can be settled fairly and reasonably.

The lawyer should consider the appropriateness of alternate dispute resolution (ADR) to the resolution of issues in every case and, if appropriate, the lawyer should inform the client of ADR options and, if so instructed, take steps to pursue those options. ${ }^{63}$

Similarly, bar associations are also actively encouraging the use of privatizing tools in the civil justice process through best practices statements $^{64}$ and model codes of conduct. ${ }^{65}$ These moves have been clearly mandated for some time and have developed out of significant reform initiatives such as the "CBA Task Force Report", which described the "adoption of a dispute resolution approach" to "litigation practice" as a "new professional obligation."66

Finally, law schools - following their United States counterparts as well as the recommendations in the "CBA Task Force Report" contemplating a "revolutionizing" of legal education toward the increased

${ }^{63}$ Nova Scotia Barristers’ Society (NSBS), Legal Ethics Handbook, rr. 10.2-10.2A, online: NSBS <http://www.nsbs.org/legalethics/chapter10.htm> (footnote omitted).

${ }^{64}$ See e.g. CBA-British Columbia Branch, "Our Court System and Solving Disputes”, online: CBA-British Columbia Branch $<$ http://www.cba.org/BC/public_media/lawyers/432.aspx> .

${ }^{65}$ For example, in a similar spirit to the settlement and ADR provisions of the NSBS's Legal Ethics Handbook, supra note 63, the CBA's Code of Professional Conduct provides that: "Whenever the case can be settled reasonably, the lawyer should advise and encourage the client to do so rather than commence or continue legal proceedings. The lawyer should consider the use of alternative dispute resolution (ADR) for every dispute and, if appropriate, the lawyer should inform the client of the ADR options and, if so instructed, take steps to pursue those options.” CBA, Code of Professional Conduct, c. IX.8, online: CBA <http://www.cba.org/CBA/activities/pdf/codeofconduct06.pdf> (footnote omitted).

66 "CBA Task Force Report”, supra note 32 at 62-63. For a discussion of these reforms and obligations, see "Dispute Resolution, Access to Civil Justice and Legal Education", supra note 8 at 750 . 
treatment of $\mathrm{ADR}^{67}$ - have dramatically increased their focus on ADR and related courses and training. As I have written elsewhere,

The face of the legal academy, like other justice system stakeholders, has also changed over the past three decades. Included in this change are the teaching and research of dispute resolution, which have clearly taken on new and critical importance. For example, in American law schools in 1976, "there was no subject category for ADR or mediation.” In 1992, more than 94 percent of these schools offered dispute resolution courses. And the trend did not stop then. Since 1999, "the level of interest in dispute resolution - and in particular in the teaching of dispute resolution - has risen exponentially.” A 2002 American commentary indicated that "more than 500 law professors identify themselves as teaching ADR.” A similar "exponential[]" increase in dispute resolution teaching has occurred in Canada. According to the "CBA Survey," "it is clear that there is increased interest in and emphasis on [A]DR in all law schools."68

Taken together, the expression of all of these voices and preferences - federal and provincial governments (expressed in the form of significant court reforms), judges, lawyers, law societies, bar associations, law schools and clients - has led to a clear and increasing privatization of much of the civil justice system.

\section{ADMINISTRATIVE SYSTEM}

The second part of the public dispute resolution system that I focus on in this article is the administrative system, and in particular, privatization initiatives within federal and provincial administrative

\footnotetext{
${ }^{67}$ See supra note 32.

68 “Dispute Resolution, Access to Civil Justice and Legal Education”, supra note 8 at 754-755 (citations omitted). For further materials on the issue of ADR and legal education, see Trevor C. W. Farrow, "Dispute Resolution and Legal Education: A Bibliography” (2005) 7 Cardozo J. Conflict Resol. 119.
} 
processes. In the same way that courts play a central role in our processes of democratic governance, so too do administrative regimes. This role can be seen clearly in the mission statement of the Québec Human Rights Tribunal (QHRT), for example, which states that the QHRT “contributes in its own way, as part of the third pillar of government, to the building of an egalitarian society, with proper regard for the principles of fundamental justice and procedural fairness., ${ }^{, 69}$

Research for this part of the article involved searching hundreds of provincial and federal statutes and legislative provisions regarding administrative-based dispute resolution processes. It also involved searching publicly-available materials for many of these regimes in search of information regarding non-statute-based materials on administrative dispute resolution processes that engage some privatization component. This research turned up hundreds of instances of the use of mediation, arbitration or other forms of ADR tools within administrative legislation databases (several of these instances are discussed below) ${ }^{70}$

\section{A. Federal Processes}

There are many examples of federal administrative processes that actively encourage and engage various privatizing tools. ${ }^{71}$ For example, the Canadian Human Rights Commission (CHRC), established pursuant to

\footnotetext{
${ }^{69}$ QHRT, “The Human Rights Tribunal”, online: Québec Government $<$ http://www.tribunaux.qc.ca/mjq_en/TDP/index-tdp.html>.

${ }^{70}$ Like with the privatization reforms in the civil justice system discussed above, reference must be made to the clear government preferences and policies - discussed supra part IV - that have also led to the inclusion of various privatizing tools in these administrative tribunal initiatives.

${ }^{71}$ As mentioned, numerous federal administrative regimes actively promote and employ privatizing initiatives as part of their dispute resolution processes. In addition to those discussed in this part of this article, see e.g. the Immigration and Refugee Board of Canada, Immigration Appeal Division (IAD), “Alternative Dispute Resolution (ADR) Program Protocols” (amended 13 January 2003), online: Government of Canada $<$ http://www.irb-cisr.gc.ca/en/references/legal/iad/adr/protoc_e.htm>, Canadian Transportation Agency, "Resolving Disputes Through Mediation", online: Government of Canada <http://www.cta-otc.gc.ca/mediation/disputes/index_e.html\#1/>.
} 
the Canadian Human Rights Act, ${ }^{72}$ has adopted a wide-ranging ADR program that actively promotes the simplification and privatization of many disputes brought to the CHRC. According to the CHRC's materials:

The Commission actively promotes ADR with disputing parties and with other interested groups because it is timely and effective. In February 2003, the Commission created the ADR Services Branch with a mandate to strengthen the service and actively promote it with stakeholders. The Branch offers two forms of ADR: mediation and conciliation. $^{73}$

Within its former 1999 pilot project and now within its established ADR programs, which in 2005 were brought under the newly created Dispute Resolution Branch, the use of ADR has been quite wide-spread and reportedly successful. According to its most recetly-available annual report, nearly half of the cases brought to the CHRC in 2006 were settled, mostly using a CHRC-appointed conciliator or mediator. ${ }^{74}$

As is discussed further below, ${ }^{75}$ one of the important aspects of the CHRC's approach to ADR is its recognition that not all cases are suitable for ADR. However, notwithstanding this recognition, it maintains a clear preference for resolving many cases using one of its ADR resources. As the CHRC states, "ADR is not the answer to every human rights issue but it is a healthier route to take than adjudication in many cases.",76

\footnotetext{
${ }^{72}$ R.S.C. 1985, c. H-6, s. 26.

73 CHRC, “Overview: Alternative Dispute Resolution, What is ADR?”, online: Government of Canada <http://www.chrc-ccdp.ca/adr/what_is_it-en.asp>.

${ }^{74}$ CHRC, 2006 Annual Report at 7 (Resources, Publications, Reports: "Effectiveness of the Business Model"), online: Government of Canada <http://www.chrcccdp.ca/publications/ar_2006_ra/page7-en.asp>.

${ }^{75}$ See infra notes 76 and 172 and surrounding text.

${ }^{76}$ CHRC, Overview, Alternative Dispute Resolution, "Why Use ADR?", online: Government of Canada <http://www.chrc-ccdp.ca/adr/why_use_it-en.asp>.
} 
There are many reasons cited for pursuing ADR, all of which are consistent with the general reasons behind most of the government and civil justice reform initiatives discussed above. ${ }^{77}$ For example, according to the CHRC, the "reasons to choose" ADR include that: it "works quickly"; is "confidential"; is "better for participants and their future relationships than confrontation and adjudication"; and the "participants set the agenda" and the "solutions". 78

Another example of a federal process that actively promotes the use of ADR tools is the Commission for Public Complaints Against the RCMP (CPC), which was established in 1988 by the Federal Government. The CPC is designed to provide a "civilian review" process regarding the conduct of members of the Royal Canadian Mounted Police (RCMP). ${ }^{79}$ According to the the CPC, it actively promotes the use of ADR for the resolution of complaints:

Once the CPC analyst determines the relevant facts and understands the goals of the complainant, the analyst explains the citizen's options for dealing with his or her concern. In appropriate cases, the analyst invites the complainant and the RCMP to work together informally to resolve the complaint. The complainant always retains the right to file a formal complaint.

Where the complainant elects to resolve the complaint informally, the CPC analyst serves as a facilitator, helping the complainant obtain information by enlisting the aid of the senior RCMP officer in the jurisdiction where the problem arose. When facilitating in this manner, the analyst provides the RCMP with a summary of the concern

\footnotetext{
${ }^{77}$ Supra parts IV and V.

${ }^{78}$ CHRC, Overview, Alternative Dispute Resolution, “Why Use ADR?”, supra note 76.

${ }^{79}$ CPC, "Welcome”, online: Government of Canada <http://www.cpccpp.gc.ca/DefaultSite/Home/index_e.aspx?ArticleID=1>.
} 
expressed by the complainant, normally on the same day that the citizen raises the concern. ${ }^{80}$

Again, the merits of this process are well-known. Speed, cost and efficiency are important justifications for the CPC's use of alternative more private - processes. However, it is clear that the CPC and the RCMP, particularly given budgetary realities, encourage the use of ADR to enable them to deploy their energies on matters that they view as more pressing. For example, according to the CPC:

The informal resolution of complaints against members of the RCMP has been highly successful - the needs of complainants often can be addressed more quickly than through the formal process. Informal resolution makes it possible for both the CPC and the RCMP to deploy scarce resources to higher priority work. ${ }^{81}$

Provided other endeavors are more pressing, of course that policy approach makes sense (assuming the intake analyst who first receives the complaint gets the complaint-channeling process correct). However, to the extent that a case of significant public importance is run through the CPC's ADR channel - because of a bad decision by an intake analyst, bad faith on the part of the RCMP or the CPC, or simply because of "scarce resources" that are deemed to be needed for "higher priority work" concerns need to be raised. These are the concerns of this article (that are further developed below). ${ }^{82}$ Given the active promotion of ADR by the $\mathrm{CPC}$, it is clear that - like the CHRC - its strong preference, which is also in-line with the Federal Government's stated preference, ${ }^{83}$ is to try to resolve disputes using ADR tools.

${ }^{80}$ CPC, 2005-2006 Annual Report, "Informal resolution in action”, online: Government of Canada <http://www.cpc-

cpp.gc.ca/DefaultSite/Reppub/index_e.aspx?articleid=1203\#3.5.1>.

${ }^{81}$ Ibid. (emphasis added).

${ }^{82}$ See e.g. infra part IX.

${ }^{83}$ See e.g. supra part IV. 


\section{B. PRovincial Processes}

As with the federal administrative regime, provincial processes are increasingly promoting and employing privatizing initiatives as part of their dispute resolution systems. Numerous examples were discovered in the research for this article. ${ }^{84}$

As a preliminary matter, several provinces - including British Columbia and Ontario - have enacted administrative legislation of general application that allows for individual administrative regimes within those jurisdictions to create and administer ADR processes. These legislative initiatives are clearly in-line - and are in fact motivated by - the overall government preferences in these and other jurisdictions to promote the use of privatized dispute resolution mechanisms. ${ }^{85}$ For example, according to the B.C. legislation, "The chair of the tribunal may appoint a member or staff of the tribunal or other persons to conduct a dispute resolution process. ${ }^{, 86}$ Similarly in Ontario, tribunals are given broad authority to develop and administer privatizing ADR regimes, including mandatory regimes. According to the Statutory Powers Procedure Act,

A tribunal may make rules...classifying the types of proceedings that come before it and setting guidelines as to the procedural steps or processes (such as...alternative dispute resolution mechanisms, expedited hearings) that apply to each type of proceeding and the circumstances in which other procedures may apply...

\footnotetext{
${ }^{84}$ In addition to the tribunal processes discussed below, see e.g. the Alberta Energy and Utilities Board (“AEUB”), “What about Appropriate Dispute Resolution?” online: AEUB $<$ http://www.eub.gov.ab.ca/bbs/public/adr/ADRPamphlet.pdf>.

${ }^{85}$ Discussed further supra part IV.

${ }^{86}$ Administrative Tribunals Act, S.B.C. 2004, c. 45, s. 28(1).
} 
A rule...may provide that participation in an alternative dispute resolution mechanism is mandatory or that it is mandatory in certain specified circumstances. ${ }^{87}$

Of particular interest to the arguments presented in this article are tribunals that deal with significant public interest values and resources. One area of particular focus - in which these sorts of ADR mechanisms have been put in place - includes the various provincial human rights tribunal regimes. For example, the Manitoba Human Rights Commission (MHRC) "encourages" the use of ADR processes as part of its overall dispute resolution process. ${ }^{88}$ Similarly, the B.C. Human Rights Tribunal (BCHRT) offers various forms of "off the record" ${ }^{89}$ ADR settlement processes including mediation, early evaluation, structured negotiation and final determinations on the merits. ${ }^{90}$

The policy reasons behind the BCHRT initiatives, again, include speed, simplicity (often including reduced costs) and privacy. Specifically, according to the BCHRT, parties "may be interested in a settlement meeting for a number of reasons. Settlement meetings are often the quickest and simplest method of resolving disputes, and they are confidential. If there is a settlement, there will not be a public hearing." 91 Similar policy "advantages" are identified as part of the ADR-based settlement initiatives of the Alberta Human Rights and Citizenship

\footnotetext{
${ }^{87}$ R.S.O. 1990, c. S.22, ss. 4.7, 4.8(4).

${ }^{88}$ MHRC, Annual Report 2005 at 9 (“Complaint Process - Overview: Mediation”), online: Manitoba Government <http://www.gov.mb.ca/hrc/english/publications/annualreports/annual-report-05.pdf $>$.

${ }^{89}$ BCHRT, “Guide 4 - The Settlement Meeting” at 2, online: B.C. Government $<$ http://www.bchrt.bc.ca/guides_and_information_sheets/guides/Guide4_2005.pdf>.

${ }^{90}$ Ibid. at 1.

${ }^{91}$ Ibid. at 2 (emphasis added).
} 
Commission (AHRCC) ${ }^{92}$ and the Nova Scotia Human Rights Commission (NSHRC). For example, according to the NSHRC:

While information from a Human Rights Board of Inquiry hearing is made public, information exchanged during settlement initiatives is kept confidential. This allows participants of settlement initiatives to discuss their situation openly and candidly without fear of repercussion. ${ }^{93}$

Other provincial administrative bodies that deal with significant public resource issues include environmental protection tribunals. Again, in this segment of the administrative process, significant privatizing initiatives have been put in place. For example, the Alberta Environmental Appeals Board (AEAB) - an independent body that reviews decisions regarding development approval, water licenses, reclamation certificates and enforcement orders ${ }^{94}$ - actively encourages ADR. According to its materials, the AEAB "places a high value on its mediation program and encourages participants to use mediation as the primary way to resolve appeals that come before the Board."95

In addition to its policy statements, the AEAB's preference for resolving disputes through its $\mathrm{ADR}$ process can also be seen from its

\footnotetext{
${ }^{92}$ The AHRCC regime includes a "conciliation” process, which specifically provides the parties to a complaint with a "without prejudice" (confidential) dispute resolution alternative. AHRCC, Publications and Resources, Complaint Process, "Conciliation”, online: Alberta Government $<$ http://www.albertahumanrights.ab.ca/publications/Information_Sheets/Text/Info_Compl aint_Process.asp>.

${ }^{93}$ NSHRC, "Introduction to Settlement Initiatives", online: Nova Scotia Government $<$ http://www.gov.ns.ca/humanrights/PDFdocs/Settlement_E.pdf >. Other provinces with human rights tribunal regimes that employ similar kinds of private ADR process include New Brunswick, Newfoundland and Labrador, Ontario (see further infra notes 173-179 and surrounding text), P.E.I. and Saskatchewan.

${ }^{94}$ AEAB, "Welcome”, online: Alberta Government $<$ http://www.eab.gov.ab.ca/index.htm>.

${ }^{95}$ Ibid. (emphasis added).
} 
settlement statistics. For example, according to the AEAB's mediation information:

From April 1, 2004 to March 31, 2005, the Board held 18 mediations, all of which were successfully resolved, resulting in a 100 percent success rate for this reporting year. Since the Board's inception in 1993, it has conducted 139 mediations with 116 being successfully resolved. This reflects an overall success rate of 83 percent. $^{96}$

Similar environmental assessment and protection issues are dealt with by the Ontario Environmental Review Tribunal (OERT), which also actively deploys ADR techniques for the resolution of disputes. For example, according to the OERT:

Mediation is offered to all parties (except in matters under the Niagara Escarpment Planning and Development Act, and Oak Ridges Moraine Conservation Act, 2001) and is conducted after the preliminary hearing and generally 30 days prior to the commencement of the main hearing... The Tribunal [in 2007-2008] will continue to offer these services in every appeal and, upon request, in all applications filed in order to encourage parties to resolve their issues. ${ }^{97}$

\footnotetext{
${ }^{96}$ AEAB, 2004-2005 Annual Report at 24 (“Mediation Program”), online: Alberta Government <http://www.eab.gov.ab.ca/pub/2004-05-AR.pdf>. By comparison, the settlement rates using these sorts of ADR-based processes in the human rights tribunal context are moderate to strong. For example, according to the AHRCC, more than 50 percent (394 complaints) of the 749 complaints that were resolved in the 2005-2006 year (of a total of 778 complaint files opened) were resolved using the AHRCC's conciliation process. AHRCC, Annual Review, April 1, 2005-March 31, 2006 at 10 ("Conciliated files"), online: Alberta Government $<$ http://www.albertahumanrights.ab.ca/publications/Annual_Review/Ann_Rev_0506.pdf $>$. Almost 60 percent were resolved that way the previous year at the AHRCC. Ibid.

97 OERT, 2007-2010 Business Plan at 4, 10, online: Ontario Government $<$ http://www.ert.gov.on.ca/>.
} 
Further, even after an initial settlement attempt, or if "parties choose not to participate" following the preliminary hearing, mediation services "are offered by the Tribunal throughout the Hearing process, upon request."98 Because a "number of the Tribunal Members are certified to conduct mediation", 99 it is clear - even at the hearing stage - that mediation is actively considered and promoted by the OERT.

\section{Settlements Involving Matters of Public Interest}

Notwithstanding policy-based provisions in various tribunal regimes that often encourage or require mattes of "public interest" to proceed to a tribunal hearing, ${ }^{100}$ or at least to be resolved pursuant to public interest values, ${ }^{101}$ there are numerous cases being settled using private ADR tools that involve matters of significant public interest and importance that receive little or no public scrutiny or attention.

Some of these settlements involve matters that are discontinued and not pursued at all through either the formal or informal tribunal processes. ${ }^{102}$ Nothing further may be heard of these matters. Of those that do continue into the system, many are resolved based on confidential processes and are only reported on in a very summary fashion, if at all, in the tribunal's public materials. For example, private settlements at the tribunal level have recently involved matters of public interest such as: subsidized housing discrimination; ${ }^{103}$ physical disability and gender

98 OERT, Annual Report, April 1, 2005-March 31, 2006 at 4 (“Mediation”), online: Ontario Government <http://www.ert.gov.on.ca/>.

99 OERT, 2007-2010 Business Plan at 4 (“Mediation”), supra note 97.

100 See e.g. AEAB, “About Mediation: When is Mediation not Appropriate?”, online: Alberta Government <http://www.eab.gov.ab.ca/mediation_about.htm>. See also infra notes 106 and 172 and surrounding text.

${ }^{101}$ See e.g. CHRC, Overview, Alternative Dispute Resolution, “Why Use ADR?”, supra note 76 . See also infra notes 171-172 and surrounding text.

102 See e.g. AEAB, 2004-2005 Annual Report at 36, supra note 96.

103 See e.g. MHRC, Annual Report 2005 at 11, supra note 88. 
discrimination, often in the context of employment and services; ${ }^{104}$ significant complaints about police mistreatment involving potential discrimination of members of First Nations; ${ }^{105}$ environmental protection matters; ${ }^{106}$ and immigration matters. ${ }^{107}$ It is the public interest aspect of these privatized settlements that also brings these administrative tribunalbased ADR initiatives within the scope of the concerns developed further below in this article. ${ }^{108}$

\section{NON-COURT OR TRIBUNAL-BASED LEGISLATIVE ADR PROCESSES}

The third aspect of the public dispute resolution system that I focus on in this article is the growing and increasingly important aspect of the system that lies in between the formal state-sanctioned court and administrative regime-annexed privatization initiatives discussed in the previous two parts of this article and the purely private realm of dispute resolution processes that occur everyday completely outside of the state's influence. It is this third aspect of the system that was also fully engaged in the Dealership case. ${ }^{109}$

What I am specifically talking about in this part of the article typically involves arbitration processes that are set up pursuant to agreements between individuals or private entities but that are, at the same

\footnotetext{
104 See e.g. AHRCC, Annual Review, April 1, 2005-March 31, 2006 at viii ("Resolution and adjudication of human rights complaints: summary of results”), supra note 96.

105 See e.g. CPC, 2006-2007 Annual Report, “Appendix 3: Informal Resolution of Complaints”, online: Government of Canada <http://www.cpccpp.gc.ca/DefaultSite/Reppub/index_e.aspx?articleid=1439\#8>.

${ }^{106}$ See e.g. AEAB, 2004-2005 Annual Report at 36, supra note 96.

107 See e.g. IAD, “Alternative Dispute Resolution (ADR) Program Protocols” (amended 13 January 2003), online: Government of Canada <http://www.irbcisr.gc.ca/en/references/legal/iad/adr/protoc_e.htm>

108 See infra part IX.

109 Supra part II.
} 
time, enabled by federal ${ }^{110}$ or provincial arbitration ${ }^{111}$ or mediation statutes. ${ }^{112}$ They are, as such, hybrid processes in the sense that they are partly public regimes given the enabling and sanctioning legislation pursuant to which they receive many of their powers. And they are partly private regimes in the sense that they are initiated by private agreement and, once underway, they also allow parties essentially free reign to conduct proceedings that are fully private and largely out of reach of all state actors (including the courts). Perhaps the most convenient recognition of this form of "privatization" is a recent minority judgment of Bastarache and LeBel JJ. of the Supreme Court of Canada:

Exclusive arbitration clauses operate to create a "private jurisdiction" that implicates the loss of jurisdiction of stateappointed forums for dispute resolution, such as ordinary courts and administrative tribunals, rendering contractual arbitration both different and exclusive of the later entities...Contractual arbitration has also been described as creating a "private justice system" for the parties:... "From a theoretical standpoint, arbitration is a private justice system that ordinarily arises out of an agreement. Thus, it has a contractual source and an adjudicative function”...

What makes contractual arbitration a "private jurisdiction" or "private justice system" is the degree of freedom the parties have in choosing the manner in which their dispute will be resolved:

Arbitration is therefore the settling of disputes between parties who agree not to go before the courts, but to accept as final the decision of experts of their choice, in a place of their choice, usually subject to laws agreed upon in advance and usually under

\footnotetext{
${ }^{110}$ See Commercial Arbitration Act, R.S.C. 1985 (2nd Supp.), c. 17.

${ }^{111}$ See e.g. Alberta Arbitration Act, R.S.A. 2000, c. A-43.

${ }^{112}$ See Nova Scotia Commercial Mediation Act, S.N.S. 2005, c. 36.
} 
rules which avoid much of the formality, niceties, proof and procedure required by the courts...113

By way of background, the introduction and establishment of the arbitral system in Canada - which largely tracks historic international commercial arbitration developments - has also been recently summarized by Deschamps J. of the Supreme Court of Canada:

International arbitration law is strongly influenced by two texts drafted under the auspices of the United Nations: the Convention on the Recognition and Enforcement of Foreign Arbitral Awards, 330 U.N.T.S. 3 ("New York Convention"), and the UNCITRAL Model Law on International Commercial Arbitration, U.N. Doc. A/40/17 (1985) (“Model Law”).

The New York Convention entered into force in 1959. Article II of the Convention provides that a court of a contracting state that is seized of an action in a matter covered by an arbitration clause must refer the parties to arbitration. At present, 142 countries are parties to the Convention. The accession of this many countries is evidence of a broad consensus in favour of the institution of arbitration...Canada acceded to the New York Convention on May 12, 1986.

The Model Law is another fundamental text in the area of international commercial arbitration. It is a model for legislation that the UN recommends that states take into consideration in order to standardize the rules of international commercial arbitration. The Model Law was

${ }^{113}$ Dell Computer Corp. v. Union des consommateurs, supra note 9 at paras. 132133 (references omitted). See further ibid. at para. 200, at which Bastarache and LeBel JJ. state that "the effect of exclusive arbitration clauses is to create a 'private jurisdiction' that implicates the loss of jurisdiction of state-appointed authorities for dispute resolution, such as domestic courts and administrative tribunals.” 
drafted in a manner that ensured consistency with the New York Convention...

The final text of the Model Law was adopted on June 21, 1985 by the United Nations Commission on International Trade Law ("UNCITRAL”). In its explanatory note on the Model Law, the UNCITRAL Secretariat states that it:

...reflects a worldwide consensus on the principles and important issues of international arbitration practice. It is acceptable to States of all regions and the different legal or economic systems of the world.

(Explanatory Note by the UNCITRAL secretariat on the Model Law on International Commercial Arbitration, at para. 2)

In 1986, Parliament enacted the Commercial Arbitration Act, R.S.C. 1985, c. 17 (2nd Supp.), which was based on the Model Law... ${ }^{114}$

Provincial arbitration legislation has similarly been enacted across Canada that also reflects this widespread acceptance of the policies and practices of this world-wide dispute resolution process. ${ }^{115}$ Key components of arbitration legislation typically include: broad subject matter coverage; significant ability to vary many provisions of the legislation; limited court intervention; wide procedural flexibility; binding

\footnotetext{
${ }^{114}$ Ibid. at paras. 38-41, Deschamps J. (majority).

${ }^{115}$ See e.g. supra note 111.
} 
awards; limited appeal rights; powers of enforcement; and powers to award costs. ${ }^{116}$ In short, once commenced:

....arbitration is a creature that owes its existence to the will of the parties alone...the parties to an arbitration agreement are free, subject to any mandatory provisions by which they are bound, to choose any place, form and procedures they consider appropriate...The choice of procedure does not alter the institution of arbitration in any of these cases. The rules become those of the parties, regardless of where they are taken from. ${ }^{117}$

Of particular significance to typical arbitrating parties, and to this article, is the overwhelming purpose of arbitration legislation to provide parties with a powerful, flexible, and confidential dispute resolution process that is largely out of the reach of the public court system. This underlying policy principle can be seen in the many legislative debates that led to the development of these regimes. For example, according to legislative debates regarding Ontario’s arbitration legislation:

The purpose of the Arbitration Act, 1991, is to provide a framework for the private settlement of disputes that will be as clear as possible for those who use it, while preserving the fairness of the process. The ability of an unwilling party to delay or derail an arbitration has been reduced to a minimum. The parties are generally free to set their own rules for arbitrations - that is, to override the act - so they have a great deal of flexibility. However, the law and the courts will ensure that the parties stick to their

\footnotetext{
${ }^{116}$ See e.g. Alberta Arbitration Act, supra note 111 at ss. 2, 3, 6, 20, 37, 44-45, 48, 49 and 53.

${ }^{117}$ Dell Computer Corp. v. Union des consommateurs, supra note 9 at paras. 5152, Deschamps J. (majority). See further ibid. at para. 133, Bastarache and LeBel JJ., discussed further supra at note 113 and surrounding text.
} 
agreement to arbitrate, do not proceed unfairly, and abide by the result when it is given. ${ }^{118}$

Further policy debates leading to the enactment of these powerful legislative tools belie many legislators' intentions to increase the use of arbitration as a way to off-set the use of public resources in resolving certain civil matters as well as some legislators' views that arbitration should even be mandated for some commercial circumstances. These sentiments can be seen, for example, in the following statements in the debates leading up to amendments to Manitoba's arbitration legislation:

We on this side acknowledge the value of arbitration as a way to resolve disputes. Arbitration usually costs less to the disputing parties. At least, we recognize that it can cut down on some costly legal costs and pretrial procedures. It certainly costs less to the taxpaying public, because the expensive judicial system is not called on to resolve the disputes. Arbitration is often, although not always - but usually faster than litigation. It is also informal, accessible and flexible, which meet the needs of the parties to a greater extent than formal litigation. Of course, arbitration also allows privacy. It is confidential, as long as one of the parties does not pursue an appeal.

It is clear that arbitration does have a very important role in our society and, indeed, it is my firm belief that we should rely more on alternative dispute resolution. We should be looking for not only a greater reliance on arbitration but other ways of resolving disputes outside of the courts.

I think one of the greatest arguments to support my belief is that when there are limited resources to deal with conflicts between individuals and limited resources to deal with

118 Ontario, Legislative Assembly, Official Report of Debates (Hansard), (5 November $1991)$ at 1550 (Hon. Howard Hampton) (emphasis added). 
Criminal Code infractions, we have to think why are we putting so many resources into the resolution of disputes between, for example, two large corporations that may have extensive resources and, yet, are going head to head in a battle over many years... We really, I think, have to think in larger terms about how we are using public resources to solve disputes between certain kinds of parties and, in that regard, I wonder if we should not be looking toward a more affirmative statement or a more effective way of getting parties to use arbitration as an alternative to civil litigation, including requiring arbitration clauses in certain commercial contracts. ${ }^{119}$

The freedom and power that are clearly provided by these legislative regimes has made arbitration increasingly popular, particularly as a method to resolve commercial disputes. In the United States, for example, reports indicate that total case filings for the American Arbitration Association (AAA) dramatically increased over the 10 year period from 1993 to 2003 (from over 60,000 cases in 1993 to over 230,000 cases in 2003). ${ }^{120}$ In Canada, ADR - specifically including arbitration - is a similarly favoured dispute resolution regime, particularly within the corporate sector. For example, a number of significant corporate entities and leading Canadian law firms have signed the ADR Institute of Canada's "Dispute Resolution Pledge", which "commits signatories to willingly consider and suggest alternative dispute resolution processes in appropriate situations prior to turning to the courts."

${ }^{119}$ Manitoba, Legislative Assembly, Official Report of Debates (Hansard), Vol. XLVII, No. 59, Orders of the Day (11 June 1997) at 1520 (Hon. Gord Mackintosh).

${ }^{120}$ Reported in Thomas J. Stipanowich, “ADR and the 'Vanishing Trial': The Growth and Impact of “Alternative Dispute Resolution’” (2004) 1 J. Emp. Leg. Stud. 843 at 872.

${ }^{121}$ ADR Institute of Canada, Rules \& Pledges, "Dispute Resolution Pledge: A Corporate Policy Statement”, online: ADR Institute of Canada <http://www.amic.org/>. For a list of signatory corporations and law firms, see ibid. at About Us, ADR Leaders, "Pledge Signatories”. 
Further, not only is arbitration increasingly popular, it is also in large measure fully recognized as an established part of (or alternative to) the overall civil justice system. This recognition starts at the top of our Canadian court system. For example, according to LeBel J.:

In general, arbitration is not part of the state's judicial system, although the state sometimes assigns powers or functions directly to arbitrators. Nonetheless, arbitration is still, in a broader sense, a part of the dispute resolution system the legitimacy of which is fully recognized by the legislative authorities. ${ }^{122}$

Taking this recognition of arbitration one step further, Bastarache and LeBel JJ. of the Supreme Court of Canada recently recognized the further policy of legislatures, building on Desputeaux, which "now accepts arbitration as a valid form of dispute resolution and, moreover, seeks to promote its use." ${ }^{123}$ One primary method by which the court has promoted the use of arbitration is through its deferential approach to arbitration challenges, which it recently confirmed as follows:

It is...well established that the effect of a valid undertaking to arbitrate is to remove the dispute from the jurisdiction of the ordinary courts of law...There is consequently no question that, if the arbitration agreement is valid and relates to the dispute, the Superior Court has no jurisdiction to hear the case and must refer the parties to arbitration. ${ }^{124}$

${ }^{122}$ Desputeaux v. Éditions Chouette (1987) inc., 2003 SCC 17, [2003] 1 S.C.R. 178 at para. 41.

${ }^{123}$ Dell Computer Corp. v. Union des consommateurs, supra note 9 at para. 143 (emphasis added).

${ }^{124}$ Ibid. at para. 150, Bastarache and LeBel JJ. 
In addition to recognizing the well-established nature of valid contractual agreements to arbitrate, the Court has also recently confirmed that it will only disrupt the jurisdiction of an arbitrator in limited circumstances. ${ }^{125}$

\section{JUSTIfICATIONS FOR PRIVATE JUSTICE}

The justifications for these privatizing trends - typically spoken of in terms of benefits - are well documented and include: efficiency in terms of time, money and resource management; the reduction of backlogs and costs; increased access to a dispute resolution system; the maintenance of individual (and community) relationships through improved dialogue, tailored outcomes and voluntary compliance with results; freedom to choose laws, processes and decision-makers; improved public satisfaction with dispute resolution regimes; and, of course, protection from public scrutiny through rules of confidentiality. ${ }^{126}$

${ }^{125}$ According to Deschamps J.:

First of all, I would lay down a general rule that in any case involving an arbitration clause, a challenge to the arbitrator's jurisdiction must be resolved first by the arbitrator. A court should depart from the rule of systematic referral to arbitration only if the challenge to the arbitrator's jurisdiction is based solely on a question of law...

If the challenge requires the production and review of factual evidence, the court should normally refer the case to arbitration, as arbitrators have, for this purpose, the same resources and expertise as courts. Where questions of mixed law and fact are concerned, the court hearing the referral application must refer the case to arbitration unless the questions of fact require only superficial consideration of the documentary evidence in the record.

Before departing from the general rule of referral, the court must be satisfied that the challenge to the arbitrator's jurisdiction is not a delaying tactic and that it will not unduly impair the conduct of the arbitration proceeding. This means that even when considering one of the exceptions, the court might decide that to allow the arbitrator to rule first on his or her competence would be best for the arbitration process.

Ibid. at paras. 84-86. See also Rogers Wireless Inc. v. Muroff, 2007 SCC 35 at para. 11.

${ }^{126}$ See "Privatizing our Public Civil Justice System”, supra note 8 at 16. See also "Critiques of Settlement Advocacy", supra note 8 at 292-293, citing S. B. Goldberg, 
In large measure, a significant underlying theme of many of these benefits sounds in the principle of efficiency, which has come essentially to define the modern discourse surrounding our civil justice systems. As Héctor Fix-Fierro has noticed:

[E]fficiency...has penetrated the legal and judicial systems at all levels and dimensions, from the level of society as a whole to the day-to-day operation of the judicial process, from the institutional role performed by adjudication in society to the organisational context of judicial decisions...In other words: far from being an alien value with respect to the legal and judicial process, efficiency has simply become an inseparable part of the structure of expectations we address to the legal system. ${ }^{127}$

This efficiency-based argument, as I have summarized elsewhere, essentially proceeds as follows:

When a dispute involves the private rights of $\mathrm{A} \mathrm{v}$. B, and further, when two "consenting adults" (including corporations) have chosen to move their dispute off the busy docket of our public court system and into the private boardroom of an arbitrator or mediator, current views suggest that justice is being served. The argument is that the resolution of disputes - like other goods and services should not be deprived of the benefits of freedom of

Frank E. A. Sander \& N. H. Rogers, Dispute Resolution: Negotiation, Mediation, and Other Processes (New York: Aspen Law and Business, 1999) at 8.

${ }^{127}$ Héctor Fix-Fierro, Courts, Justice and Efficiency: A Socio-Legal Study of Economic Rationality in Adjudication (Oxford and Portland: Hart Publishing, 2003) at 235 (footnote omitted) [Courts, Justice and Efficiency]. Note, however, that Fix-Fierro further comments that "economic rationality is not, and should not necessarily be, the prevalent value or the overriding concern in the context of legal decision-making." Ibid. 
movement and contract in an efficiency-seeking, innovative and expanding market economy. ${ }^{128}$

An example of this form of argument is articulated by Gillian Hadfield, who has forcefully advocated for the privatization of law particularly commercial law - in the overall spirit of "significantly decreasing the cost of law." "29 This argument is also similar to that raised by the Honourable Gord Mackintosh, for example, in the legislative debates surrounding Manitoba's arbitration legislation. ${ }^{130}$ Hadfield although recognizing that the justice system plays several important public roles in our modern democracies including protecting "individual rights" argues that when it comes to commercial law, the state should download privatize - much of its dispute resolution functions:

...the legal system...performs important economic functions such as providing the structure and regulation necessary for the operation of efficient markets. The economic sphere of law regularly deals with relationships that involve only corporate entities. Private legal regimes could provide this law without raising legitimacy concerns. ${ }^{131}$

Hadfield summarizes the basis for her argument as follows:

The rules we want in these interactions [involving corporate entities] are the rules that promote and facilitate

\footnotetext{
${ }^{128}$ See "Privatizing our Public Civil Justice System”, supra note 8 at 16 . For a further discussion of ADR's purported efficiencies, see Courts, Justice and Efficiency, supra note 127 at 123-125, 131-135. See also Colleen M. Hanycz, "More Access to Less Justice: Efficiency, Proportionality and Costs in Canadian Civil Justice Reform" (2008) 27 C.J.Q. 98 [“More Access to Less Justice”].

${ }^{129}$ Gillian K. Hadfield, “Privatizing Commercial Law” (2001) 42:1 Regulation 40 at 40 ["Privatizing Commercial Law"], online: Cato Institute $<$ http://www.cato.org/pubs/regulation/regv24n1/hadfield.pdf>.

${ }^{130}$ See supra note 119 and surrounding text.

131 "Privatizing Commercial Law”, supra note 129 at 40.
} 
efficient market relationships between corporations. In this setting, we are not interested in what is fair or just between two corporations; we are interested in what makes their economic relationship as productive and valuable as possible. That goal suggests the need to look for ways to increase the role of markets in the process of developing and administering the legal regimes that govern the relationships between corporate entities. ${ }^{132}$

Hadfield's argument rests essentially on four points: corporate relationships are different than relationships involving "individual rights"; the public need not be interested in the fairness of corporate relationships; cost reduction can be achieved through efficiency-seeking private dispute resolution mechanisms; and we should ultimately be guided by principles of efficiency - not what is "fair or just" - when making fundamental procedural policy choices in the context of commercial dispute resolution. $^{133}$

Clearly saving time, money, relationships and reputations, while at the same time increasing market efficiencies are typically good things. And if one-off dispute resolution statistics and results were the only relevant factors by which to measure a dispute resolution regime, particularly involving corporate entities, the discussion would essentially be over. Unfortunately, this narrow - litigant-based - perspective is what currently drives much of our public policy thinking and choices. For example, when debating the addition of ADR into the B.C. Administrative Tribunals Act, ${ }^{134}$ one Member of Parliament argued that:

What citizens want more often than not is an outcome and a result rather than a process. They want their problems solved. They want the relationship improved, they want the

\footnotetext{
${ }^{132}$ Ibid. Not only does Hadfield contemplate the privatization of the procedural aspects of corporate dispute resolution, she also advocates for the privatization of substantive corporate law development. See ibid. at 41.

${ }^{133}$ Ibid. at 40 .

${ }^{134}$ Supra note 86.
} 
benefit they believe they're entitled to, and they want government to stop doing what it is that is harming them. ${ }^{135}$

As such, according to the same Member of Parliament,

Anything we can do to move forward dispute resolution so that it happens sooner is, in my view, a step in the right direction, and we are doing a lot as government to try to encourage alternative dispute resolution not just in the administrative justice system but across the justice system as a whole. In fact, part of rethinking justice involves rethinking the idea of alternative dispute resolution so that it is no longer alternative but, rather, so that mediation, settlement, conciliation and settlement conferences are all part of the basic tools of all dispute resolution... ${ }^{136}$

The problem, however, is that while individuals and corporate citizens do often care about the individual outcome of their case rather (or at least typically more) than the process; when we think about the justice system as a whole, process is fundamental to an overall viable public justice system. Arguments that focus purely on efficiency or purely on individual, one-off interests lose this overall societal perspective. As is discussed in the next part of this article, there is clearly more going on in dispute resolution regimes (including at the commercial level) than simply the resolution of one-off disputes. The fundamental and just regulation of society is at stake. And unlike Hadfield, I am strongly of the view that the state should maintain not only a strong interest in the resolution of disputes involving "the lives and relationships of its citizens"; it should also do so in the context of disputes involving "corporate-to-corporate commercial dealings.",137

\footnotetext{
${ }^{135}$ British Columbia, Legislative Assembly, Hansard, Vol. 25, No. 15 (18 May 2004) at 11192 (Hon. G. Plant).

${ }^{136}$ Ibid.

137 “Privatizing Commercial Law”, supra note 129 at 45.
} 


\section{Concerns About PRivatization}

First, as a threshold matter, even the many stated efficiency-related benefits of ADR are not without their doubters. For example, some studies have shown that purported reductions in cost and increases in speed and efficiency are not always present in court-annexed ADR processes, and in any event, do not always militate in favour of increased efficiency of courts to which those ADR processes are annexed. ${ }^{138}$ But even if we assume these benefits to obtain - and it is the case that they often (although certainly not always) do - there are still remaining fundamental concerns that need to be seriously considered and discussed.

\section{A. IMPOVERISHED DEVELOPMENT OF COMMON LAW}

Critics of ADR and privatization point to the potential slow decline in the number of precedents created and the resulting erosion of the overall corpus of the common law as a result of ADR's popularity. An early but still authoritative example of this critique comes from Owen Fiss, who raised the concern that widespread settlement strategies would negatively impact the court's ability, particularly appellate courts in public interest litigation, to develop the common law. ${ }^{139}$ Tracy Walters McCormack has also - more recently - raised similar concerns. ${ }^{140}$ Eroding the sources of common law is clearly a concern, particularly given the current force and trajectory of privatizing trends.

\section{B. LACK OF PROCEDURAL PROTECTIONS}

A second concern raised by critics of ADR and privatization involves ADR's procedural protections, or potential lack thereof. Clearly one of the main benefits of ADR, as was expressly recognized, for example, in the 1991 legislative debates surrounding Ontario's arbitration legislation, is its wide-ranging flexibility, whereby parties are "generally

\footnotetext{
${ }^{138}$ Courts, Justice and Efficiency, supra note 127 at 200-203, 236.

139 See Owen Fiss, “Against Settlement” (1984) 93 Yale L.J. 1073. For a recent discussion of Fiss' critique, see "Critiques of Settlement Advocacy”, supra note 8 at 278287.

140 “Privatizing the Justice System”, supra note 1 at pt. vi.
} 
free to set their own rules...so they have a great deal of flexibility."141 However, with flexibility comes a potential significant cost. Specifically, my concern here, as I have argued elsewhere, is that without adequate public scrutiny, primarily through open court processes and the publication of precedents, there is a real danger that parties, particularly including those with power, will use the private system to circumvent public policies, accountability and basic notions of procedural fairness. ${ }^{142}$

These concerns about power and procedural fairness were clearly central to the debates surrounding Ontario's recent amendments to its arbitration legislation in the area of family law. Because I have written elsewhere on this subject, I will only very briefly develop it further here. $^{143}$ In a nutshell, prior to 2006, parties could use Ontario's Arbitration Act, 1991 for the resolution of a wide variety of disputes, including family law disputes. In so doing, they could essentially contract out of the application of progressive substantive and procedural family law protections. Recently, the Ontario Government - following significant public debate regarding the use of Ontario's arbitration legislation to sanction faith-based dispute resolution processes that potentially discriminated against women and children - sought to limit those opportunities through amendments to its arbitration legislation contained in the Family Statute Law Amendment Act, 2006 (FSLAA). ${ }^{144}$ The results of the amendments essentially were to exclude family disputes from the benefits of arbitration legislation unless the process employed by the parties complied with "the law of Ontario or another Canadian jurisdiction..."145

\footnotetext{
${ }^{141}$ Ontario, Legislative Assembly, (5 November 1991) at 1550 (Hon. Howard Hampton), supra note 118.

142 “Privatizing our Public Civil Justice System”, supra note 8 at 16.

${ }^{143}$ For my earlier comments, see "Re-Framing the Sharia Arbitration Debate", supra note 8.

${ }^{144}$ S.O. 2006, c. 1.

${ }^{145}$ Ibid. at s. 2.2(1).
} 
This move by the Ontario Government was clearly made given the obvious public interest issues engaged in family law disputes, and in particular, gender, religious, child-welfare and community-welfare interests. There is no doubt, as Hadfield would likely argue, ${ }^{146}$ that these important values are typically much more clearly identified as public interest values than those involving the rights and interests of corporations and other private actors in non-family settings. However, there are certainly occasions when the issues at stake in corporate or other private law disputes warrant significant public scrutiny. And in those cases, in my view, the public interest should be engaged through active public scrutiny of private proceedings. As such, unlike Hadfield (as I argue above ${ }^{147}$ ), justice is engaged not just when the rights of citizens are involved, but also - often - when the rights of corporations are involved.

Here is where we arrive back at the relevance of the Dealership case to the arguments in this article. Because in the Dealership case, I experienced - first-hand - numerous violations of basic procedural protections that militated to the significant detriment of John. For example, on one occasion, after repeated deposition requests for a series of documents and repeated denials by the Corporation's lawyers about their existence or relevance, a witness for the Corporation inadvertently (although properly) disclosed the fact that the documents - with knowledge of their lawyers - were in the trunk of his car that was parked just outside of the office in which the deposition was taking place. After a break to retrieve the documents (which turned out to be clearly relevant), it became clear that the lawyers for the Corporation were actively trying to conceal the existence of these documents, which contained several problematic statements relating to the corporate structure of the Corporation that undermined their theory of the case.

On another occasion, during a deposition of a different officer of the Corporation, my line of cross-examination questions was interrupted by counsel for the Corporation, who proceeded to insist on taking a break "to speak to [his]...witness". After the break, the witness returned to the

\footnotetext{
${ }^{146}$ See “Privatizing Commercial Law”, supra note 129.

147 Supra note 137 and surrounding text.
} 
room and started to answer my questions with a very different, much less forthcoming demeanour. He then quickly lost his temper, pointed at his own lawyer and at me and said - in a loud, flustered and almost panicked voice - that he was tired of "the two of us telling him what to say" in his evidence during the deposition. Never has there been clearer evidence on a deposition record of a lawyer being caught having coached his client during a break to change or tailor his evidence. Because the Dealership case was being dealt with pursuant to a private arbitration regime, the typical procedural safeguards provided for by a court were not immediately present to curb or punish the behaviour of the Corporation or its lawyers in these contexts of document hiding and witness coaching.

Now my reader might ask at this stage that, although unfortunate for John, what do these procedural injustices in a one-off corporate dispute have to do with wider public interest values? First of all, as it turned out, the Dealership case was not an isolated dispute, but rather the result of a pattern of potentially fraudulent conduct on the part of the Corporation. Throughout our retainer with John, we received a relatively steady stream of anecdotal information about similarly situated dealers in the United States finding themselves in the same position vis-à-vis the Corporation and its deceptive and aggressive business practices. We also learned, again anecdotally, about a number of similar arbitrations being pursued by or against the Corporation. Because of the strict confidentiality provisions surrounding those proceedings, however, we were not able to obtain evidence about those other arbitrations, either through informal inquiries or through repeated efforts through the production and deposition stages of the proceeding. Denials of other proceedings were all that were forthcoming from the Corporation's officers and its lawyers.

However, approximately two weeks before our arbitration hearing was set to begin, I received in the mail a list of approximately 30 or 40 similar, active arbitral proceedings in which the Corporation was involved. The list - that was included in a report to the Corporation's auditors that its lawyers had mistakenly sent to me - established clearly that the conduct engaged in by the Corporation with John was a pattern of repeated conduct that had led to similar disputes with numerous other dealers across the United States. In the face of this list, it seemed difficult for the Corporation to continue to voice - in good faith - its denial of the existence of these proceedings or their relevance. Unfortunately, because 
of professional and evidentiary reasons that prohibited us from leading the evidence in the arbitration, that is exactly what the Corporation did: it proceeded at the arbitration as though those other proceedings did not exist. And the arbitrator's judgment did not take into account the fact that the conduct about which John was complaining was a course of conduct in which the Corporation was engaging with dozens of other dealers across the United States.

Second, beyond the specifics of John's dispute with the Corporation and all of the other cases involving the Corporation, the potential ripple effect that cases such as the Dealership case could have on corporate culture, decision-making and resource allocation - for example within numerous similarly-situated North American franchise sectors - is significant. It is this behaviour modification discussion - and its overall place in the regulation of society - to which I turn next.

\section{NEGATIVE IMPACT ON DEMOCRACY}

A typical - but very narrow and misguided - understanding of the purpose of a civil justice system is that it exists primarily to resolve disputes. For example, according to a very recent treatment of civil justice reform by Alon Klement and Zvika Neeman, the "main goal of the court system is to differentiate between those who obeyed the law and those who did not, and to administer the disputes that are brought before it according to substantive law."148 Even more traditional accounts often suffer from a similar narrowness. According to Berlins and Dyer, the "courtroom" has for "centuries...been the setting for the final settlement of disputes..."149 Of course Klement and Neeman, as well as Berlins and Dyer, are partly correct: dispute resolution is one of the purposes of a civil

\footnotetext{
148 Alon Klement and Zvika Neeman, "Civil Justice Reform: A Mechanism Design Framework" (2008) 164 J. of Institutional and Theoretical Econ. at 1, online: SSRN $<$ http://ssrn.com/abstract=998028>.

${ }^{149}$ Marcel Berlins and Clare Dyer, The Law Machine, 3d ed. (London: Penguin, 1989) at 18. Similarly, when describing the British system of government, Anthony Birch makes only passing reference to the role of courts in the overall process of governing. See Anthony H. Birch, The British System of Government, 7th ed. (London: Allen \& Unwin, 1986) at 221-224.
} 
justice system. However, it certainly is not its only purpose and is not always its most important purpose.

There are many aspects to the way we order ourselves and our affairs in society. At the personal level, custom, religion, morality, tradition, etc., all often play determining roles. However, as W. H. Jennings has pointed out,

As soon as man began to live in groups, rules became necessary to govern his relations with his fellows. Even in the most primitive forms of society both the rights of the individual and the common interests of the community were bound to emerge and create a need for governing social relationships. ${ }^{150}$

Today, these social relationships - at the level of civil society - are governed by two primary regulatory tools: legislation and adjudication. And of these two tools, adjudication plays a central function in our regulatory state. As Héctor Fix-Fierro comments, courts "participate openly in the constitutional and political process..." and have become a "...real branch of government, at least in the sense that they now play an important role in shaping the general direction of society."151

The basic premise therefore behind a robust public dispute resolution system, in addition to resolving disputes, is to create a fair, predicable, accessible, just and relatively common regulatory system for all. For example, when referring to the development of the modern courts in England after the passing of the Judicature Acts of 1873-1875 and into the 20th century, R. M. Jackson has argued that the "growth and expansion of the King's Courts was doubtless an excellent thing for the building of a

${ }^{150}$ W. H. Jennings, Canadian Law: For Business \& Personal Use (Toronto: The Ryerson Press, 1951) 1-2.

${ }^{151}$ Courts, Justice and Efficiency, supra note 127 at 14-15. For further discussions, see Ian Greene, "The Courts and Democracy” in Ian Greene, The Courts (Vancouver: UBC Press, 2006) at c. 6, Peter Russell, "Judicial Power in Canada’s Political Culture” in F. L. Morton, ed., Law, Politics and the Judicial Process in Canada (Calgary: The University of Calgary Press, 1989) at c. 2. 
uniform law and standard of justice in the country..."152 And a system of justice includes not only tools for retrospective dispute resolution, but also robust tools for prospective behaviour modification and societal regulation through processes of adjudication.

There are at least three key components of the adjudicative side of this equation. First, public civil justice systems are clearly central actors in the adjudicative process. As S. M. Waddams has summarized, in addition to "statutes", the "study of law is, to a large extent, the study of...judicial decisions." ${ }^{153}$ Second, as argued above, ${ }^{154}$ in our highly complex and regulated democracies, the administrative system plays an equally, if not more important role. Again as Waddams has discussed, in a "highly regulated state...there are thousands of administrative bodies exercising very important regulatory and adjudicative powers...[A]s a practical matter, the direct effect of regulatory tribunals is often of more importance than the direct effect of legislation or of judicial decisions." Third, again as argued above, ${ }^{156}$ in addition to the state funded and created civil courts and administrative processes, there is a vast body of "alternative" justice - largely in the form or arbitration, mediation, etc. that, as the Supreme Court of Canada recognized in Desputeaux, forms a "fully recognized" part of a state's overall adjudicative process. ${ }^{157}$

152 J. R. Spencer, ed., Jackson's Machinery of Justice (Cambridge: Cambridge University Press, 1989) at 8. At the same time, however, Jackson does acknowledge that uniformity of courts in England did come potentially at the price of "competing courts which were perhaps more suitable for poor litigants and small cases.” Ibid.

153 S. M. Waddams, Introduction to the Study of Law, 3d ed. (Toronto: Carswell, 1987) at 19 [Introduction to the Study of Law].

${ }^{154}$ Supra part VI.

${ }^{155}$ Introduction to the Study of Law, supra note 153 at 19.

${ }^{156}$ Supra part VII.

${ }^{157}$ Desputeaux v. Éditions Chouette (1987) inc., supra note 122 at para. 41, LeBel J. 
Tribunals and courts, therefore, not only keep legislation in check through hearings, trials and processes of judicial review, ${ }^{158}$ they also through both the full light and the shadow of the common law - create a body of law that directly governs and indirectly guides much of what we do in our daily lives. ${ }^{159}$ This includes both individuals and corporations. As such, far from simple mechanical dispute ending tools, civil dispute resolution regimes play a central role in the regulatory processes of modern Western democracies. ${ }^{160}$

Given this central role in processes of democratic governance, the move to privatize public civil dispute resolution regimes has profound implications for how we govern ourselves in a free and democratic society. Put simply, to the extent that we are privatizing public civil dispute resolution systems, we are essentially privatizing a significant part of the way democracy is realized.

Here again we return to the Dealership case. By seeing that case as simply an A v. B case of only limited private (commercial) interest, there is no need to concern ourselves with the procedural violations that occurred in that case or even the potentially fraudulent conduct that negatively impacted John and 30 or 40 similarly situated United States

\footnotetext{
${ }^{158}$ For some foundational works and statements on judicial review, see e.g. Alexander M. Bickel, The Least Dangerous Branch: The Supreme Court at the Bar of Politics, 2d ed. (New Haven and London: Yale University Press, 1986), Robert K. Carr, The Supreme Court and Judicial Review (New York: Holt, Rinehart and Winston, 1942), Arthur A. North, The Supreme Court: Judicial Process and Judicial Politics (New York: Merredith, 1966), the Rt. Hon. Lord Denning, M.R., The Discipline of Law (London: Butterworths, 1979) at 133. See more recently Gerald Baier, Courts and Federalism: Judicial Doctrine in the United States, Australia, and Canada (Vancouver: UBC Press, 2006).

159 See e.g. Owen Fiss, “The Forms of Justice” (1979) 93 Harv. L. Rev. 1, reprinted in Owen Fiss, The Law as It Could Be (New York: New York University Press, 2003) 1, "Against Settlement", supra note 139, David Luban, "Settlements and the Erosion of the Public Realm" (1995) 83 Geo. L.J. 2619. For a collection and discussion of these and other materials on this issue, see Julie Macfarlane, gen. ed. et al., Dispute Resolution: Readings and Case Studies, 2d ed. (Toronto: Emond Montgomery, 2003) 615-620.

${ }^{160}$ For a discussion of the court's regulatory role and its relationship to the state's legislative function, see W. Kip Viscusi, ed., Regulation through Litigation (Washington, D.C.: AEI-Brookings Joint Center for Regulatory Studies, 2002).
} 
dealers. According to Hadfield, for example, we are not concerned with the "fair[ness]" of that commercial case. ${ }^{161}$ However, if we see that case, instead, as a potential opportunity not only to shut down the problematic conduct of a significant United States goods and service provider but also to send a significant signal to other similarly-situated individual and corporate actors (and lawyers) in society about the negative repercussions of engaging in that sort of conduct, opinions, policies, resource allocation, overall corporate behaviour and potentially legislation (regulating both corporations and lawyers) would likely change. That is the power of the adjudicative aspect to our processes of democratic governance. Privatizing those tool risks losing that power.

\section{Future Thinking: Justice Must TrumP EFFICIENCY}

The shift that I see being required - to avoid further jeopardizing the regulatory power of adjudication - is a shift in the overall mindset of those who work in and think about public civil dispute resolution processes and their reform. Put simply, all civil justice policy, reform thinking and implementation needs to start from a bottom-line premise based not on notions of efficiency - where, as Héctor Fix-Fierro has recognized, ${ }^{162}$ it currently lies - but rather on robust notions of justice. The two premises are not necessarily or always mutually exclusive. Often when disputes are resolved more efficiently, justice obtains. ${ }^{163}$ However, on occasions when they are mutually exclusive, and in any event, justice must be the ultimate arbiter when it comes to making significant policy choices and resource allocation decisions at all levels and regarding all players - individual and corporate - within our systems of civil justice. To do otherwise risks one of the very foundational aspects of our processes of democratic governance. As the Chief Justice of Canada recently acknowledged,

\footnotetext{
161 “Privatizing Commercial Law”, supra note 129 at 40.

162 See supra note 127 and surrounding text. See also "More Access to Less Justice”, supra note 128.

163 See e.g. supra parts III, VIII.
} 
Courts have been promoting various forms of out-of-court mediation and arbitration as a more effective way of achieving settlement and dealing with many civil cases. This is good. But the fact is, some cases should go to court. They raise legal issues that should be considered by the courts for the good of the litigants and the development of the law. ${ }^{164}$

In my view this shift in mindset and this cautionary sensibility about ADR should obtain at all three levels of the civil dispute resolution system - courts, tribunals and arbitration panels - that I discuss in this article.

\section{A. COURTS}

In the operation of civil courts, for example, all players specifically including masters and judges - should not be overly pressured into realizing economic efficiencies - backlog and cost reduction, etc. - to the down-playing of fundamental principles of justice that celebrate the public resolution of policy-making disputes, which do not only include landmark Charter and other public law cases but also, sometimes, include the day-to-day cases of A v. B. (involving both private individuals and corporations, like the Dealership case).

I am aware that masters and judges already have the power to and sometimes do - make these sorts of decisions to privilege a sensibility of justice over that of efficiency in the context of choices regarding ADR and privatization. For example, when deciding on whether to exempt a case from mandatory mediation, the court has the power to move a case off a mediation list for several reasons, including where matters of significant public interest are involved. In O. (G.) v. H. (C.D.), Kiteley J. articulated the following considerations in these sorts of circumstances:

\footnotetext{
${ }^{164}$ Rt. Hon. Beverley McLachlin, P.C., "The Challenges We Face” at "The Challenge of Delays in the Justice System" (remarks presented at Empire Club of Canada, Toronto, 8 March 2007), online: Supreme Court of Canada <http://www.scccsc.gc.ca/aboutcourt/judges/speeches/Challenges_e.asp>. For a report of these remarks, see Kirk Makin, “Top judge sounds alarm on trial delays” The Globe and Mail (9 March 2007) A1.
} 
At the risk of generalizing from the few reasons for decision and from the somewhat cryptic explanation made by the local mediation co-ordinators in the list tracking exemptions, it would appear that the following criteria are relevant to whether an exemption order should be granted:

- whether the parties have already engaged in a form of dispute resolution, and, in the interests of reducing cost and delay, they ought not to be required to repeat the effort; [and]

- whether the issue involves a matter of public interest or importance which requires adjudication in order to establish an authority which will be persuasive if not binding on other cases... ${ }^{165}$

It was the second of these types of considerations - considerations involving matters of public interest - that animated Master Beaudoin's reasons in Wilson v. Canada (Attorney General). ${ }^{166}$ In that case, the applicants challenged s. 25(4) of the Public Services Superannuation Act, R.S.C 1985 c. P-36 - regarding the definition of a "surviving spouse", which included the words "opposite sex" - as violating s. 15 of the Charter. The moving parties in the particular motion before the Master sought leave to have the proceedings exempted from a mandatory referral to mediation, as - in their view - it would "not be productive given the subject matter of the Application." ${ }^{\text {"167 }}$ Master Beaudoin, when granting the motion, gave the following reasons:

The Ottawa Practice Direction with respect to mandatory referral to mediation contemplates a referral to interestbased mediation. Through the intervention of a third party neutral, the parties are encouraged to consider a resolution of their dispute on terms that consider their broader

\footnotetext{
${ }^{165}$ O. (G.) v. H. (C.D.), supra note 48 at para. 13 (S.C.J.).

${ }^{166}$ [1998] O.J. No. 1780 (Master) (QL). Wilson was cited in the O. (G.) v. H. (C.D.) case.

${ }^{167}$ Ibid. at para. 2.
} 
interests rather than a strict consideration of their rights; often requiring the parties to arrive at a form of compromise. In this instance, the resolution of this application requires the determination of the rights of the individual applicants, not only for themselves but for all others who are similarly situated.

There is no precedent to guide the court in this matter. An article entitled The Adequacy of the Adversarial System in Charter Litigation by Robin S. Sharma in the National Journal of Constitutional Law [3 N.J.C.L.], in my view, correctly sets out the approach to be taken. At p. 119 the author cites two reasons why Alternative Dispute Resolution techniques may not be appropriate in resolving Charter disputes. With regard to the second reason the author states:

...constitutional cases, so often involving
issues of paramount societal concern, must
have the ability to influence and shape future
conduct and to prompt necessary
behavioural changes. This requires
adjudication within a public forum such as a
law court where the public interest is
represented and binding, effective decisions
are rendered.

While the author goes on to suggest that certain cases exist where compromise/settlement procedures should be considered seriously, this is not one of those cases. The ultimate disposition of this application will have implications for same sex couples throughout the country and accordingly, leave to be exempted from the referral is granted. ${ }^{168}$

\footnotetext{
${ }^{168}$ Ibid. at paras. 3-4.
} 
Mediation and other ADR processes should continue not to be encouraged in these sorts of high profile public interest cases. However, what counts as "public interest" should not be viewed narrowly as only to include these sorts of Charter challenges. While these cases are clearly important, they are not the only cases that act to shape the conduct and relationships of day-to-day people on day-to-day issues. All cases should be seen as potential candidates to be moved off the privatization track and onto - or back into - a public track. Current and overwhelming preferences for efficiency, particularly in the moments of a civil case when decisions about case management or court-annexed ADR processes are made, militate against this tendency. And not only should this shift in underlying preferences occur at the operational stage of the court's work, but also at the policy and reform levels as well.

\section{B. Administrative Processes}

The same shift in sensibility needs also to obtain at the administrative level. Clearly - to-date - government preferences for including and encouraging ADR at all levels of operation has resulted in the significant use of ADR throughout the federal and provincial administrative system. ${ }^{169}$ According to the settlement rates and statistics of some of these tribunals, the use of ADR is becoming the norm. ${ }^{170}$

Like with the court system, the problem is not that tools do not exist for these sorts of justice-based considerations. They do. For example, notwithstanding the CHRC's preference and active promotion of ADR when resolving complaints, ${ }^{171}$ it still retains the jurisdiction to review complaints on a case-by-case basis to determine whether public policy considerations militate against the use of ADR:

The Commission's focused litigation strategy allows it to support the parties at pre-tribunal mediation, while it concentrates on vigorously pursuing high-impact, public

\footnotetext{
${ }^{169}$ See supra part VI.

${ }^{170}$ See e.g. supra note 96 and surrounding text.

${ }^{171}$ Supra note 73 and surrounding text.
} 
interest cases before the Canadian Human Rights Tribunal. On a case-by-case basis, the Commission determines the scope and nature of its participation before the Tribunal after assessing such factors as whether the case raises broad policy issues, relates to major policy concerns, or raises new points of law. The Commission can also intervene in precedent-setting cases before courts and administrative tribunals dealing with human rights issues. ${ }^{172}$

Of course "high-impact" cases that involve the "public interest" and "major policy concerns" should - typically - be subjet to the scrutiny and rigour of the public tribunal process. However, as argued above in the context of the Dealership case (although admitedly not an administrative case), there are many instances in which cases that are not high impact or high profile turn out to be significant in terms of overall societal regulation. Those cases, too, should become candidates for staying on the public track. At the moment, my fear is that the sensibility of privatization systematically leads these sorts of cases to the private track.

Another good potential example for thinking on this point includes initaitves of the Ontario Human Rights Commission (OHRC) in the area of monitoring and regulating settlements. The OHRC, as guided by s. 33(1) of the Human Rights Code ${ }^{173}$ is encouraged to pursue settlements of complaints, including through its mediation processes. ${ }^{174}$ However, notwithstaning this strong policy preference, it retains the ability at least partially to control the process and content of settlements. For example, settlements reached pursuant to mediation processes that engage matters of

${ }^{172}$ CHRC, 2006 Annual Report at 8 (Resources, Publications, Reports: "Public Interest Litigation”), supra note 74.

${ }^{173}$ R.S.O. 1990, c. H.19, as amended. The new Human Rights Amendment Act, 2006 will come into effect on 30 June 2008. See S.O. 2006, c. 30. Significantly, among other major changes, complaints will now typically be dealt with by the Human Rights Tribunal of Ontario (HRTO).

${ }^{174}$ See OHRC, “Internal Guide to Processing Complaints, “Mediation”, online: OHRC $<$ http://www.ohrc.on.ca/en/commission/complaint_processing_guides/internal/pdf > at 44 . Mediation will also be used by the HRTO. See HRTO, "Mediation and Adjudication", online: HRTO <http://www.hrto.ca/english/about/Adjudication.asp\#mediation>. 
public interest must be approved by the OHRC to ensure the interests of the public are protected. ${ }^{175}$ Further, settlements that engage matters of public interest may be publicized by the OHRC, even if the parties to the mediation process do not consent. ${ }^{176}$ Finally, the OHRC specifically discourages the use of confidentiality clauses in minutes of settlement. ${ }^{177}$

All of these are good considerations in the context of making decisions about the use of mediation or other privatizing tools at the tribunal level. However, my fear is that when these decisions actually get made - i.e. whether to proceed to mediation or whether to push for the publication of a settlement, etc. - the principle of efficiency trumps that of public interest and justice. Although the public interest is an issue that is obviously important to the OHRC, my concern here is hightened after looking, for example, at the OHRC's list of occasions in which it considers mediation not to be appropriate, which may include:

- The existence of a section 34 request that staff have assessed as likely to result in a "not deal with" recommendation and decision;

- The complaint or the respondent[s] rejects mediation and wishes to proceed directly to the formal process of investigation;

- Neither side is willing to consider a settlement;

- One side is seeking punitive action. ${ }^{178}$

There is nothing in this list that specifically references the "public interest”, which - in my view - should be of central concern to these sorts of privatization considerations. Further, when it comes to publicizing settlements, the OHRC's stated position is that it “initiates publicity in a

\footnotetext{
175 See OHRC, “Internal Guide to Processing Complaints, "Mediation”, supra note 174 at 45.

${ }^{176}$ Ibid. at 46.

${ }^{177}$ Ibid. at "Settlement”, 54.

${ }^{178}$ Ibid. at "Mediation”, 47.
} 
very small proportion of its cases."179 Although not every case is a matter of wide-spread notariety or media attention, like with many cases pursued in court (or in arbitral proceedings, including cases like the Dealership case), there is real value vis-à-vis societal regulation in maintaining the public profile of the resolution of those disputes. Again, our over-riding sensibility should be guided by principles of open justice, not private efficiency.

\section{Non-Court OR Administrative-Based Legislative ADR PROCESSES}

The third level of the civil dispute resolution system that needs to ensure that justice is retained as a - and ideally the - animating sensibility is the legislatively-sanctioned ADR regime (e.g. arbitration sanctioned by federal or provincial arbitration legislation). ${ }^{180}$ Because of arbitration's very existence as a private alternative to the public system, it is on first blush difficult to envisage overly aggressive policy changes that will lead to dramatic increases in the level of publicity of this typically private system. These changes will be particularly difficult to effect if arguments such as those advanced by Gillian Hadfield ${ }^{181}$ or the Honourable Gord Mackintosh ${ }^{182}$ primarily drive our thinking.

However, it was these sorts of arguments of privileging justice over efficiency that guided the Ontario Government's reform of its Arbitration Act, 1991 to exclude the legislation's application to family law arbitrations that, in effect, do not comply with what Ontario deems to be in the interests of justice (regardless of an outcome's efficiency). ${ }^{183}$ While the interests at stake in these reforms were particularly important (involving rights relating to equality, religion and the family), there are many other circumstances in which the results of an arbitral process

\footnotetext{
${ }^{179}$ Ibid. at "Settlement", 53.

${ }^{180}$ Discussed supra part VII.

${ }^{181}$ Supra note 129 and surrounding text.

${ }^{182}$ See supra notes 119, 130 and surrounding text.

${ }^{183}$ Discussed supra notes $143-145$ and surrounding text.
} 
should not be deferred to by a public court or sanctioned by the force of the state's enforcement tools and should, potentially, become part of the public record. The Dealership case, in my view, is an example of one of those cases. Our current preferences for the sanctity of contract and the sanctity of the private arbitration process militate against reforms that would preference notions of justice over notions of free market efficiency. In my view, these current preferences risk jeopardizing the foundations of our regulatory state.

\section{CONCLUSION}

Fundamentally changing a central aspect of a democracy's regulatory structure, one would think, should require significant debate and far-reaching public consultation. To-date, no such wide-ranging and robust debate or consultation - on a fully informed basis - has characterized the modern and wide-ranging tendency to privatize our public systems of civil dispute resolution. On my reading of the policy thinking and legislative history of this overall trend of privatization, while there has been some significant discussion within the justice system particularly concerning the merits of ADR, there is little or no awareness at the level of the general public about the significance of these issues or their potential concerns as they relate to the overall workings of society.

As was recognized during legislative standing committee statements surrounding Ontario's approach to ADR in 1990, "Because of arbitration being a private matter, most members of the public are unaware of the many matters that are resolved by this technique and this mechanism." 184 This statement is still by and large true today. And while there is at least some debate about how the common law is created and administered in the public sphere, often through discussions framed in support or critique of "judicial activism", ${ }^{185}$ the public is generally ignorant of a much more prevalent - at least in terms of our public civil justice system (to the extent that $95-98 \%$ of cases in that system, for

\footnotetext{
${ }^{184}$ Ontario, Legislative Assembly, Official Reported of Debates (Hansard), (14 February 1990) at J-102 (Gordon F. Henderson).

${ }^{185}$ See e.g. the discussions cited in "Re-Framing the Sharia Arbitration Debate", supra note 8 at n. 50 .
} 
example, settle by some alternative process ${ }^{186}$ ) - trend away from an accountable form of adjudicative governance. As I have said elsewhere: "it never ceases to amaze me that the public, while typically up in arms about the 'activism' of our public judges, is largely silent (or ignorant) about the significant decisions made everyday by private decision-makers behind closed-doors.”187

Fundamentally privatizing our public civil dispute resolution systems merits significantly more public debate - and understanding than what has to-date occurred. Whether and how we continue actively to privatize our tools of civil justice are questions that will have a dramatic impact not only on how people resolve individual disputes, but also on how we as a collective govern ourselves in our democracy. There are clearly well documented reasons for pursuing privatization, at least in some cases. However, the current trend of privatization - largely in the name of cost and efficiency - is being conducted without adequate public debate about, let alone public understanding of, all of the implications positive and negative - of this clear policy choice. ${ }^{188}$ We must recognize the potential strengths of dispute resolution alternatives. However, only through responsible, public participation in the development of these processes will we avoid an erosion of our core democratic values significantly embodied in a strong rule of law system, simply in the name of speed and efficiency. We cannot treat justice simply as an externality. Again quoting from the Chief Justice of Canada:

In this country, we realize that without justice, we have no rights, no peace, no prosperity. We realize that, once lost, justice is difficult to reinstate. We in Canada are the inheritors of a good justice system, one that is the envy of the world. Let us face our challenges squarely and thus

\footnotetext{
${ }^{186}$ Discussed supra note 60 and surrounding text.

187 “Re-Framing the Sharia Arbitration Debate”, supra note 8 at 82 (footnote omitted).

${ }^{188}$ See ibid.
} 
ensure that our justice system remains strong and effective. ${ }^{189}$

Ensuring that our justice system remains "strong and effective" does not mean selling it out to the lowest bidder. Whether we are talking about courts, tribunals or legislatively-sanctioned private arbitration panels that enjoy the coercive enforcement powers of the state, justice - not efficiency - must be our fundamental guide in determining how these bodies operate and how they will be reformed going forward.

${ }^{189}$ Rt. Hon. Beverley McLachlin, P.C., “The Challenges We Face”, supra note 164 at “Conclusion”. 